QH

45

S18

1866

MAMM.

DE BETEEKENIS

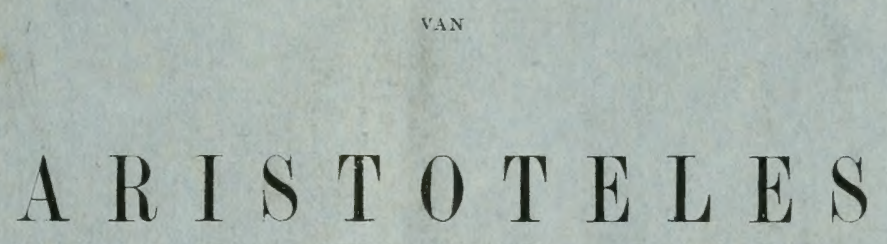

A R I S T 0 T E L E S

VOOR DE ONTWIKKELING DER NATUURLIJKE GESCHIEDENIS,

Dr. M. SALVERDA.

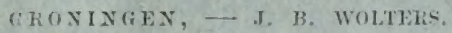

1866.

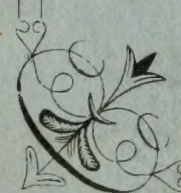





\section{DE BETEEKENIS}

VAN

\section{A RISTOTELES}

VOOR DE ONTWIKKELING DER NATUURLIJKE

GESCHIEDENIS. 
Snelpersdruk. - Gebrs. Hoitsema. - Groningen. 


\section{DE BETEEKENIS VAN}

\section{A R I S T 0 T E L E S}

VOOR DE ONTWIKKELING DER NATUURLIJKE

GESCHIEDENIS.

\section{REDEVOERING,}

ter aanvaarding van het Hoogleeraarsambt aan de Hoogeschool

te Groningen,

DEN $6^{\text {den }}$ DECEMBER 1866

UITGESPROKEN

DOOR

Dr. M. S A L V E R D A.

GRONINGEN. - J. B. WOLTERS.

1866 . 
„Lob und Tadel muss ohne Rückhalt ausgesprochen werden. Piëtät gegen die Vergangenheit fordert von uns, für jede gute Leistung mit unserem Danke bereit zu sein; eine gleiche Piëtät gegen die Jetztzeit heisst uns aber, vor einer Uebertreibung uns zu hüten, welche Lobeserhebungen der Vorausgegangenen zu Schmähungen gegen die Lebenden wachen würde."

LEWES.

(Naar de vertaling van Prof, victor carus.) 
Ten allen tijde heeft - gelijk het door whewerL teregt is opgemerkt - in den mensch de geneigdheid bestaan, in zijn streven naar wetenschap zich antesluiten aan mannen, die, uitmuntende door talent en begaafd met meer dan gewone geestkracht, zich vrij wisten te maken van de dwalingen hunner dagen; mannen, die hunnen tijd - gelijk men het noemt - zijn vooruit geweest. Men volgt hen na; de denkbeelden door hen verkondigd worden uitgangspunt voor allerlei bespiegeling en met de meest ongerijmde overdrijving hunner beteekenis tracht men a. h. w. te vergoêlijken, dat het zelfstandig onderzoek al spoedig voor allerlei deductiën heeft plaats gemaakt, dat commentaren in de plaats getreden zijn van nieuwe waarnemingen, dat inductie en zelfstandige kritiek voor belezenheid en geleerdheid het veld hebben geruimd. Iedere wetenschap heeft hare autoriteiten gehad.

Maar vroeger of later komt de tijd, dat andere groote geesten de beoefenaars der wetenschap komen wakker schudden uit hunnen droom; en met het herleven der eigen-werkzaamheid de steeds knellender geworden banden des gezags verbreken. Dan is het, 
dat de aan zichzelven teruggegeven wetenschappelijke mensch, met al wat in hem is, in opstand gekomen, vergeet, dat hijzelf de schuld draagt zijner slavernij, en, in nieuwe overdrijving vervallende, de verdiensten van zijnen vroegeren meester, zoo veel hij kan, verkleint. Wie is 'er, die niet aanstonds, op welk gebied hij zich bewege, voorbeelden dezer dubbele overijling aantewijzen weet!

Maar niemand ook, wiens geschiedenis (want die van iemands denkbeelden is immers zijne geschiedenis) meer de waarheid van het bovenstaande bewijst, dan ARistoteles.

Hadden zijne eerste navolgers zich niet bepaald tot de bloote verklaring zijner schriften, maar ook getracht, dwalingen daarin voorkomende te verbeteren en het ontbrekende, zooveel zij konden, aantevullen; al spoedig zien wij de commentatoren zich vernederen tot maar al te wijdloopige verklaringen woord voor woord; er worden uittreksels gemaakt, paraphrasen geleverd; anderen daarentegen stellen zich ten doel, de verwarringen optehelderen, die zich in al die verklaringen van lieverlede hadden opgehoopt; de commentatoren worden zelven gecommenteerd. En Arabieren en Grieken deelen tesamen den arbeid, telkens wederom nieuwe stof ontleenende aan zichzelven. Moet het ons bevreemden, dat, in het laatst der twaalfde eeuw, de "Commentator bij uitnemendheid" - gelijk hij werd genoemd - (hij had trouwens in eene vertaling in het Syrisch zijnen text gevonden, omdat hij het Grieksch niet magtig was) verklaarde, „dat door ARistoteles alle wetenschappen tot den hoogsten trap van volmaking waren gebragt, dat de gansche gezigtskring: van het 
menschelijk weten door hem was overzien, en de grenzen daarvan voor altoos vastgesteld."

Van dat standpunt tot dogmatisme is slechts ééne schrede. 't Was niet genoeg', zichzelven te hebben tot slaven gemaakt; ook anderen moest hetzelfde juk worden opgelegd. En, waar aan den eenen kant met de meest mogelijke spitsvindigheid de woorden van den gevierden wijsgeer naar de heerschende denkbeelden moesten worden verwrongen, werd zịnn gezag aan elke andere meening met bitterheid ontzegrd. Ja zelfs zou de tijd aanbreken, waarin het gezag van den godsdienst den heerschenden dwang: kwam versterken en iedere afwijking worden zou tot ketterij.

Wel heeft zich nu en dan eene beweging in teg*enovergestelde rigting geopenbaard: wèl hebben zich b. v. stemmen doen hooren ten gunste van PLATo vooral; wèl hebben de theologen, met reden voor zóó mag'tig’en mededing’er beducht, meer dan éénmaal zijne werken ten vure gedoemd; de plaats echter, door ARIstoтELEs ingenomen, verloor hij niet, om integrendeel, door mannen als ALBERTUs MaGNus en THOMas aquinas op nieuw gecommenteerd, weldra een standpunt te bereiken, gelijk nog nimmer door hem ingenomen was. Toen zou het gebeuren, dat men van de hoogleeraren der wijsbegeerte vóór hun optreden de verklaring vergde, zich naauwkeurig te zullen houden aan zijne leer; toen werd bij koninklijk edict de overtreder een " homo temerarius, arrogans et impudens" verklaard, wiens werken behoorden te worden vernietigd.

Maar ook toen reeds begonnen - eerst van de zijde der mathematici — stemmen zich te verheffen, 
die het waagden, de langvergode stellingen in twijfel te trekken en te weêrleggen, en bereidde de geest des 'Tijds, langzaam maar zeker, den weg: voor hen, die de zeventiende eeuw hebben gemaakt tot eene, beroemd om hare aankanting tegen alle autoriteit.

Volslagen ommekeer! De man, zonder wien wetenschap eene onbestaanbaarheid werd geacht, wordt op den achtergrond geschoven; slechts spaarzame uitgaven van den éénmaal onmisbaren vinden nog' hun weg; de vergoding van weleer heeft plaats gemaakt voor vaak bitteren spot: de "leeuw van Stagira" wordt met den inktvisch vergeleken, zich aan naauwkeurige beschouwing onttrekkende in eene wolk van inkt.

Voor het eerst op het einde der achttiende, vooral in het begin der negentiende eeuw zien we intusschen weêr op nieuw de aandacht op ARIstoteles gevestigd, en eene studie naar den eisch des Tijds door nieuwe uitgaven mogelijk gemaakt. Stemmen als die van LESSING, van HEGEL vooral, verheffen zich voor den miskende; hamiton, macGillavry, cuvier, GEOFFROY ST. HiLAIRE, DE BLAINVILLE, JOHANNES MÜLLER, - zelven mannen van onbetwist gezag spreken zich op gelijke wijze uit - en, niet te vreden met den grooten wijsgreer te waarderen in zijnen tijd en alle natuurwetenschap a. h. w. te laten beginnen van hem, wil men zijne waarde tot in onzen tijd hebben uitgestrekt, en laat men - niet zelden met opzettelijke verkleining der verdiensten van latere onderzoekers voor ARISTOTELES aanspraken gelden op belangrijke ontdekkingen der nieuwere wetenschap.

Doch in onze eeuw is evenmin als in de $17 \mathrm{e}$ 
voor autoriteiten plaats. Reeds is een teg'enwig't in de schaal gelegd. Lewes - de bekende biograaph van Gozthe, de schrijver der "Sea-side studies" en der, vooral in TAUCHNITz uitgave veel verspreide "Physiology of common Life" — heeft voor een tweetal jaren ARISTOTELEs en zijn werk tot onderwerp gemaakt van een belangrijk onderzoek, vooral op de natuurwetenschap gerigt. En - eene zekere dubbelzinnigheid in sommige zijner uitspraken, waarop reeds elders gewezen werd, buiten rekening gebrag't - wordt door dezen schrijver de gewone bewering, dat aristoteles van eenig deel der natuurwetenschap de grondlegger of de wetgever zou zijn geweest, zonder meer, voor » onphilosophische overdrijving verklaard, die de gansche beteekenis der historie ondergraaft." Ja hij gaat zoover, te gelooven, „dat mein de geschiedenis van ellke dezer wetenschappen beginncu lian, zonder Anistoteles zelfs te noemen."

Heeft hij juist gezien, en is zijue kritiek vrij van dezelfde overijling, waarvan hij — in de tegrenovergestelde rigting - Cuvier en anderen, niet zonder bitterheid, beticht? Welke is in der daad de beteekenis van aristoteles voor de ontwikkeling der natunuwetenschap? Ziedaar eene vraago, waarvan de belangrij]kheid wel door niemand zal worden bestreden, die met mij de groote waarde der historische ontwikkeling eener wetenschap erkent, en de volstrekte onmisbaarheid daarvan gevoelt bij hooger onderwijs.

Vergunt mij, uit het laatste oogpunt, met de bespreking dezer vraag mijnen werkkring aan deze hoog'eschool te aanvaarden, en verleent mij daarbij Uwe welwillende aandacht! 
Het is eene onbetwistbare waarheid, dat de oude Grieken, hoe groot zij zich ook hebben getoond in hunne voortbrengselen van lkunst, van stijl en van wijsgeerig onderzoek, in de beoefening der natuurwetenschap met oneindig minder geluk hebben gewerkt. De vraag kan niet uitblijven: Wat mag daarvan de reden zijn?

Er zijn 'er' geweest, die gemeend hebben, de verklaring te kunnen leveren met de bewering, dat te weinig aandacht aan de waarneming geschonken werd, en dat van die gelukkige combinatiën van waarnemingen, die »ohservations provoquées", waaraan wij gewoon zijn, den naam van proefnemingen te geven, weinig of geen gebruik werd gemaakt; dat daarentegren te veel werd toegregeven aan de alom heerschende voorliefde voor afgetrokken bespiegeling:

$\mathrm{Al}$ aanstonds zou hier kunnen worden in het midden gebrag't, - hetgeen door Lisbig voor weinige jaren uitgesproken werd - dat \# het experiment, niet minder dan de bereliening, slechts een hulpmiddel is voor het proces des denkens, - vergeeft het germanisme in mijne vertaling! — en dat, zal het eenige beteekenis hebben, daaraan in elk geval en met noodzakelijkheid de gedachte dient vooraf te gaan". En in zooverre had hij regt, te beweren, "dat een empirisch natuuronderzoek in den vulgairen zin eigenlijk niet bestaat." Zeker zouden, zonder meer, de g'rootste rijkidom van waarnemingen, de talrijkste experimenten nimmer tot de ontdekking van ook maar ééne enkele natuurwet hebben geleid. Maar met rede deed reeds whewelu opmerken, dat de Ouden wel degelijk hebben waargenomen en ge- 
ëxperimenteerd. En aau ideeën heeft het hun evenmin ontbroken: hunne energie is ook in dezen groot geweest! Maar van beide hebben zij een onbedachtzaam gebruik gemaakt. En de beschuldiging van LEwES is volkomen waar: " $\mathrm{Zij}$ hebben waargenomen en uit hunne waarneming besluiten afgeleid, maar hunne waarneming was vlugtig, en hunne besluiten waren overijld." Dat de val-snelheid van eenig. ligchaam evenredig wezen zou aan zijn gewigt, had eenen schijn van warheid; en het vallen van eenen steen en eene veder had het immers bewezen?! Aan verder onderzoek, aan contrôle wordt niet gedacht - ten minste de beteekenis daarvan niet begrepen; GALILEï wordt door de aanhangers der oude leer bespot, en zijne tegrenproeven vinden geen geloof. En 'er komt g’eene verbetering', vóórdat veler schipbreuk in die controle het kompas heeft leeren kennen, zonder hetwelk de zee des onderzoeks niet dan bij toeval met geluk bevaren wordt.

Waarom?

Omdat de wetenschap zich langzaam haast, en de mensch van nature ongeduldig is.

Gebrek aan g’enoegraam materiaal, het g'emis van de onontbeerlijkste werktuigen van den nieuweren tijd lieten den Ouden niets overig dan het onderzoek van schijnbaar onbeduidende bijzonderheden, of het wagen van hypothesen. En, niet tevreden met zoo g'ering'e uitkomsten, hebben zij bij de subjectieve methode hulp gezocht. - Is het niet de geschiedenis van het "electrisch fluïdum", van de "levenskracht" - oud, maar eeuwig nieuw? -- Toen moest de subjectieve methode de overhand verkrijgen. Ons voordeel boven hen is, dat wij hebben geleerd - 
met schade en schande hebben greleerd - onzen geest in dezen te mistrouwen; dat wij, ons natuurlijk ongeduld temperende en bedacht op onze ligtcreloovigheid, de empirische methode hebben op den voorgrond gebragt.

Ik wil eenen dier oude wijsgeeren zelven laten spreken. Hij verhaalt ons van den ijver, waarmede hij in zijne jengd naar de oorzaken der dingen te zoeken plag't, zonder, tot zijne bittere teleurstelling', iets nader te komen tot zijn doel. Daar vangt hij uit de schriften van ANATAgOras de verklaring op, dat de greest de oorzaak en de verordineerder van alle dingen is. Met gretigheid neemt hij haar aan, en overlegt bij zichzelven, hoe die alles ordenende greest elk ding zoodanig inrigt, als daarvoor het beste is. Wie de oorzaak van eenig verschijnsel wenscht te doorgronden, die make uit, wat het beste en meest passende zou zịn. En voortaan neemt hij, den grond aanvoerende, dien hij voor den sterksten houdt, datg'ene aan als waarheid, wat met dien grond schijnt overeen te stemmen; wat daarvan afwijlit, is niet waar.

Wie ooit, al ware 't niet dan oppervlakkig, van de wijsbegeerte van pLATo - want hij was het, dien ik spreken liet - liennis heeft genomen, dien is het niet onbekend, tot wat buitensporige bespiegelingen zijne methode hem - bij al zijne onbetwistbare grootte - heeft geleid.

Zeventien jaren $\operatorname{lang}$ is hij, eerst de leermeester, vervolgens de vriend van ARIstoteles geweest.

Maar de lecrling week spoedig van den meester af.

Geboren en aanvankelijk opgegroeid in eene stad, waarvan de ligroing met het zuidelijk g'edeelte der 
golf van Napels vergeleken wordt, kon het wel niet anders, of hij moest zich aangetrokken voelen tot de beschouwing der natuur. En zijne opvoeding als de zoon van eenen Asclepiade werlste die rigting: grootelijks in de hand. Al zijn de opgaven omtrent de anatomische kennis dier tijden en het anatomisch onderwijs, dat bij de Asclepiaden een deel der eerste opvoeding reeds schijnt te hebben uitgemaakt, ooli nog zoo overdreven, er was maar weinig positieve liennis noodig, om de ongerijmdheid van pLATo's physiologische redeneringen te doen doorzien; en de zucht tot onderzoek van den geboren naturalist lion op den duur met zulke bespiegrelingen geenen vrede hebben. Zou ik onregt hebben, indien ik in ARIsToTELEs' voorliefle voor natuurwetenschap eene voorname aanleiding zag tot zijne afwijking van pLATo en diens wijsbegreerte?

Hoe dit zij, tegenover dezen, die aan de zinnelijke waarneming alle beteekenis betwist, zien wij ARIsтотеLis geen ander punt van uitgang erkennen, dan juist deze. In spijt van plato's bedenking, dat in het zoogrenaamde zinsbedrog een bewijs harer onwaarde moet worden gezien, leert ARIstoteles, dat het niet de zintuigen zijn, die hebben gefaald, maar dat de fout in de verkeerde duiding onzer gevaarwordingen is g'eleg'en. Krijgen wij door zintuigelijke waarneming kennis van het bijzondere, de kennis van het algemeene moet lang's den weg. der inductie worden gezocht. Wel verre dat, g’elijk de meester had beweerd, alle erkentenis eene bloote heriunering zou wezen, een herleven a. h. w. ran reeds voorafbestaande denkbeelden; wel verre dat van eenige idee alle overigen zouden kumnen wor- 
den afgeleid, omdat ze logisch zijn verbonden, wijst de leerling als eenigen grondslag van volledige erkentenis volledig'e ervaring aan; en het grevaar der Platonische methode, het over het hoofd zien van feiten en het afleiden van een overijld besluit uit weinige g'egevens, ontg'aat hem niet.

Is het te verwonderen, dat men, bij den inderdaad kolossalen omvang zijner kennis, voor de juistheid zijner inzigten a. h. w. het bewijs, ARIstoteles den "vader der inductieve wijsbegeerte" heeft genoemd?

Toch zou ik, ondanks dit alles, vreezen, dat men zoo sprekende, schuldig wordt aan groote vooringenomenheid. Aristoteles is geenzins zonder voorg’ang'er's geweest. Nog' daargelaten, dat het onbillijk is, met cuvier hen te beschuldigen van onwetendheid, wier werken voor ons moeten zijn verloren geg’aan; er zijn er - ik wil slechts wijzen op socrates - van wien wij met zekerheid weten, dat reeds in hunne leer de kiem gevonden wordt der methode, later door ARISTOteles opgevat met al de kracht van zijn genie.

En dan - bij al de scherpte, waarmeê de eischen der inductieve methode door hem zijn niteengezet, bij al den nadruk, warmeê hij heeft verlang'd, dat toch " in elk geval aan de waarneming zou worden gehoor gegreven boven de theorie" - hoe vaak blijkt hij de toepassing zijner methode te hebben nit het oog verloren!

Is hij niet, de "werkzaamheid van het wetenschappelijk scepticisme" ontberende, als roorgegraan in liet veronachtzamen der waarneming, die hij zoo aangeprezen had; en heeft hij niet maar al te zelden daaraan de noodige voorzigtigheid besteed en de een- 
maal gedane waarnemingen geverifiëerd? - Is niet, toegevende aan zijne zucht tot het opsporen van "eindoorzaken" de "grrondleg'ger der inductieve methode" in de praktijk maar al te dikwijls metaphysicus geweest?

Waar wenden wij ons om het antwoord op deze viagen beter dan tot de natuurwetenschap, en in de eerste plaats tot haar door ARIstoteles met groote voorliefde beoefend onderdeel, de natuurlijke geschiedenis der dierenwereld?

Het is er echter ver van af, dat wij van hare beoefenaars een eenstemmig oordeel hebben te verwachten. Zoo zegt ons, in zijne geschiedenis der natuurwetenschappen, cuvier, over het algemeen genomen onuitputtelijk in den lof van Aristoteles, niets minder dan het volgende:

"Men moet hem houden voor eenen der grootste warnemer's, die immer hebben bestaan; even ongetwijfeld is hij het meest buitengewone génie classificatew , dat immer door de natuur is voortgebrag.".

En weinig later volgt:

"De Histonia animalium is niet zoo zeer eene eigenlijk gezegde dierkunde, d. w. z. eene reeks van beschrijvingen der verschillende dieren;" (eene trouwens minder grelukkigre bepaling?!) » zij is veeleer eene soort van algemeene anatomie, waarin het algemeene in de organisatie der verschillende dieren wordt ter sprake gebragt; waarin humne overeenkomst en hun verschil, op het vergelijkend onderzoek der organen gegrond, worden uiteengezet, en waar de grondslagen worden aangenomen voor de meest juiste hoofdverdeelineren."

Ware dit niet overdreven, dan zeker zou aan ARIs- 
Toteles, naast zijne historische, cene groote absolute beteekenis nimmer mogren worden ontzegd!

Maar hooren we nu Liswes!

"Streng genomen, is er in de Historia animalium geenerlei wetenschap - niet eens eene stelselmatige behandeling, die op wetenschap gelijlit; niet ééne goede beschrijving is er te vinden. Eene anatomische verhandeling is het boek niet; eene beschrijvende dierkunde óók niet; eene philosophia zoölogica even min. Eene verzameling is het van opmerkingen over dieren, over hunnen bouw, over hunne gelijkheid en hun verschil, over hunne gewoonten; en als verzameling is het werk kolossaal; maar, op zijn gunstigst opgevat, is hier eene stelsellooze verzameling van détails, de laatste bovendien zelden van waarde, vaak onnaauwkeurig."

Wél is het oordeel gunstiger over de bekende verhandeling over de voortplanting, maar ook daar worden de verwijten van slordigheid in de aanname van feiten, van onvolledigheid, enz. herhaald.

En inderdaad, het kost weinig moeite, uit de talrijlie geschriften van ARIstoteles eene menigte voorbeelden samentelezen, warop maar al te veel aftedingen valt.

Dat - om el ten minste enkelen te noemen volgens zijn beweren voor de bevruchting van het patrijzenwijfjen niet meer noodig is, dan dat het onder den wind van het mannetjen kome, terwijl het op zekere tijden zelfs voldoende blijkt, dat het alleen zijne stem hoort, als het orer haar henenvliegrt; lilinkt óns voorzeker vreemd, maar wordt in verband met de opvattingen dier tijden zéer verklambaar. Mar de bewering, dat de leeuw greene halswervels 
bezit, doch in plaats daarvan slechts één enlrel halsbeen, is zeker niet gegrond op anatomisch onderzoek. Dat, zoowel bij den mensch als bij schapen, geiten en varkens de mannetjens een grooter gretal tanden dan de wijfjens zouden bezitten, „terwijl dit punt bij de overige dieren nog niet was onderzocht, "zou door een oppervlakkig onderzoek zijn weerleg'd. Dat de muizen zouden sterven, als zij water drinken gedurende den zomertijd, behoort voorzelier niet tot hunne natuurlijke geschiedenis. De bewering, dat de dollehondsbeet de beliende noodlottige gevolg'en heeft bij alle dieren, met uitzondering alleen van den mensch is minstens onverklaarbaar. De verklaring', dat het eene dwaling is, aantenemen, dat de longen de oorzaak zijn der kloppingen van het hart, orndat dit laatste verschịnsel alleen bij den mensch wordt opgemerkt - "hij toch" alleen kan in hoop en verwachting leven" - geeft Lewes in der daad het reg't, te vragen, of Anistoteles wel ooit een' vog'el heeft in de hand gehad. Dat de mensch onder alle dieren de meeste naden heeft aan den schedel (en de man wederom meer dan de vrouw) en wél opdat dit ligchaamsdeel zacht uitwasemend zij, is eene niet weinig phantastische deductie uit hoogst onvolkomen waarnemingen. En de theorie, dat de mensch noadwendig onder alle dieren het digtst behaarde hoofd bezit, ten gevolge van diezelfde reden en om de vochtigheid der hersenen (want waar de meeste rochtigheid en de meeste warmte zijn, moet ook de lirachtigste wasdom zich openbaren) sluit zich aan die beschonwing waardiglijk aan. Het berig't, dat de mensch het eenige dier is met vleesch aan de onderste extremiteiten zal ook den niet-anatoom verbazen. 
Maar ARIstoteles lient er de oorzaak van: opdat het bovendeel des ligchaams ligt zij, en de mensch dat gemakkelijk drag'e, heeft de natuur de groote massa van het bovendeel wegrgenomen en naar de benedenste deelen verlegd: daarom zijn deze vleezig en bovendien tot het zitten geschikt; waaraan de mensch in tegrenstelling van het viervoetig gedierte, dat kan blijven staan zonder moede te worden! - behoefte heeft. Maar door deze inrigting is dan ook al het beschikbare materiaal opgrebruikt en er blijft niets overig voor een' staart!

Belagchelijk, niet waar? Ik zal het u niet tegenspreken, maar u alleen het oordeel herinneren, dat men na 2250 jaren over een goed deel onzer reel geprezen hedendaagsche wetenschap uitsprekien zal.

Voor een deel lion intusechen van aristoteles wel niet anders worden verwacht. De beoefening der menschelijke ontleedkunde, die grondslag van alle verder ontleedliundig onderzoek, werd door de heerschende denkbeelden van den tijd, waarin hij leefde, in hooge mate bemoeijelijkt; en een volledig onderzoek schijnt van die zijde tot de onmogelijkheden te hebben behoord. En - al zijn de meeningen over dit punt ook thans nog verschillend - het feit, dat hem b. v. de spieren en hare werking volstrekt onbekend rijn gebleven, dat hij van de beteekenis der zenuwen, waarran er een paar door hem beschreven zijn, evenmin iets begreep als van het bestaan van een zenuwstelsel ${ }^{1}$ ), dat er tusschen slagaderen en aderen nimmer door hem wordt onderscheid gemaakt, schijnt het niet de meening te bevestigen, dat aristoteres voor zijne liemnis van het 
menschelijk ligchaam wel geene andere bronnen heeft gehad, dan de berigten aangaande de inbalseming’en, en het slagveld - dat, in één woord, zijne ervaringen meer die van lijksopeningen zijn dan die van eigenlijke anatomie. Voeg daarbij de waarschijnlijkheid, dat Hippocrates evenmin menschenlijken had bestudeerd, en dat het, 450 jaren later', door Galenus nog niet werd gedaan.

Maar, mog'e men hieruit veel verklaren van hetgeen aan ARISTOTELEs onbekend gebleven is, zijne onjuiste opgaven verdedigt het evenmin als cuvier's vergoêlijking van dit zelfs door hem erkende feit, dat de meerderheid zijner navolgers nog slechter waargenomen heeft. Dat (om slechts iets te noemen) het hart, hetgeen hij - het zij hier ter loops aangemerkt - als oorsprong der peezen ( (ที̃ pa) aannam, niet ligt "hooger dan de longen, ter plaatse waar de trachea zich in tweeën vertalit," kon hij toch weten, evenzeer als dat b. v. de menschelijke nier niet "gelapt is als die van het rund."

En wat kon er worden van biologische beschouwing'en, waar aan den grondslag der anatomie zóó veel ontbrak. Op dat gebied deed dan ook het zoeken naar " eind-oorzaken", niet zelden g'evonden in krachten (gelijk vooral de warmte), die men niet kende en waarvoor de hulpmiddelen van onderzoek veel later eerst zouden worden verschaft, dwalingen op dwalingen hoopen, en resultaten verkrijgen, waarin van de inductieve methode geen spoor meer te herkennen was.

Wil men een enkel voorbeeld?

Wamneer eene vrouw, lijdende aan zekere riekte (Lewes maakt er scharlakenkoorts van) in eenen 
spiegel riet, zal de opperrlakte ran dezen met eene soort van bloedigen wasem beslaan. - "Dat komt," zegt ARISTOTELEs, "omdat het oog niet alleen indrukken ontvangt van buiten, maar ook op de dingen buiten reageert en die in beweging brengt. Het $0^{\circ}$ is rol bloedvaten, en daar het bloed gedurende de koorts onstuimig en ontstoken is, zoo is ook het oog, al kunnen wij dit niet aantoonen, koortsachtig en geagiteerd; de lucht geraakt daardoor in beweging en brengt de beweging over op de oppervlakte van den spiegel. De gepolijste oppervlakte nu van het glas is in hooge mate gevoelig voor alle bewegingen, en daarom worden zij daarop zigtbaar."

Of is het volgende beter?

") De dieren, die te vele en te dikke vezelen hebben in het bloed, zijn van nature aard-achtiger

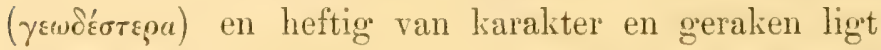
van toorn buiten zichzelven. Want de toom maakt warm, en het vaste verwarmt, wanneer het warm geworden is, meer dan het vloeibare: de vezels nu zijn hard en aardachtig, zoodat er a. h. w. damp-

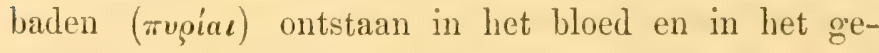
moed eene opwelling doen ontstaan. Daarom zijn stieren en evers toorniger en geraken zij ligt in woede; want het bloed dezer dieren is het rijkste

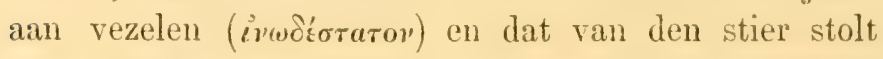
het spoedigste van allen.

Maar misschien zou cuvier u er op hebben g'ewezen, dat deze redenering toch nog beter is dan vaN HeLMoNT's betoog over de giftigheid van het stiervleesch, die — $\operatorname{nog}^{2}$ in 1650 - schrijven lion: "Wilt ge weten, waarom het bloed van een' stier 
giftig is, maar dat ran den os gezond en onschadelijk, ofschoon hij de broeder is van den stier? De reden is deze: de stier is, als hij wordt greslag't vol heimelijken weêrstand en wraakzucht, en deelt het karakter der wraak mede aan zijn eigen bloed. Een stier sterft met grooteren gloed van wraakzucht dan eenig' ander dier."

Dezelfde onvolledigheid van waarneming nu, dezelfde overijling in het maken van gevolstrekking'en, waarvan wij zoo even enkele voorbeelden hebben bijgebragt, vinden wij bij ARISTOTELEs in zijn ontleedkundig onderzoek van dieren terug. En het is LEwes niet tegren te spreken, dat hoevele op zichzelve staande bijzonderheden ook worden vermeld, ook daar eene ware ontleedliunde in de meeste gevallen ontbreekt. Het is inderdaad onbegrijpelijk, hoe een waarnemer als Cuvier zich kon laten verleiden tot overdrijvingen als deze: "Alles is rerwonderlijk, alles is kolossaal in Anistoteles. Slechts twee en zestig jaren heeft hij geleefd en duizenden waarnemingen werden door hem gedaan tot in de kleinste bijzonderheden toe; waarnemingen, waarvan de naauwkeurigheid zelfs door de strengste liritiek niet kon worden verzwakt."

Maar veel ook staat hierteg'en over !

Hoeveel afbreuk de grebreken, waarop ik wijzen moest, aan de waarde daarvan ook mogen doen de menigte der bijzonderheden, hier uiteengezet, is in der daad verbazend, en waar is het, dat "bijna iedere regel in Anistoteles' werlien een feit berat, niet zelden eene hoourstbelangrijlie opmerking, wanrin cen aantal feiten worden gegeneraliseerd.

Dat Lewes ongrelijk heeft in zijne bewering, "dat. 
er niet ééne goede beschrijving darin te vinden zou zijn, mogen die van den Chamaeleon, van den Hippelaphus (onzen Nijlghau) bewijzen.

En vinden we niet in dezelfde verhandeling, waaruit de meest zonderlinge misgrepen door ons konden worden aangehaald, het bewijs, dat ARistoteles de beteekenis der zoötomie als grondslag der biologische wetenschappen heeft begrepen, en - al was het op nog zoo onvolkomen wijze - naar de algemeene wetten des levens heeft g'ezocht? - Dáárin hebben zijne navolger's verre bij hem achterg'estaan, en het is nog niet zeer lang geleden, dat men op nicuw heeft ingezien, wat ARIstoteles voor tweeëntwintig eeuwen niet onitging.

En worden niet, onmiddelijk na opgaven over de galblaas — ik beken het — sterk pleitende tegren zijne antopsie, over 't verwaarloozen waarvan reeds vesauius hem heeft aangevallen, naar aanleiding van zijn beweren, dat de mensch slechts een achttal ribben bezit; - worden niet onmiddelijk daarna eenig'e regelen aangretrofien over de beteekenis der uitscheidingen in het organisme, die zelfs voor eene kritiek als die van LEwes "cen tegenwigt" heeten, "tegen de vele formele teleologische verklaringen, die in de schriften van ARistoteles worden gevonden," en a. h. w. een begin zijn van philosophische anatomie! Vinden we niet in den aanhef van het tweede boek der verhandeling" "over de deelen der dieren" onze weefsels, onze orgunen op 't duidelijkst uiteengezet, nadat vooraf' op de chemische samenstelling' is gewezen? - de eerste sporen eener algemeene ontleedliunde en weefselleer, gelijk die later door BICnAT en anderen tot een' aftzonderlijken tak van wetenschap zouden worden verheven 2 ). 
En spreekt aristoteles niet, in de inleiding der Historia animalium de theorie der nhomologe deelen" uit, eerst sedert GoEThe en GEOFFroy st. HILAIRE tot reg'te waardering gekomen ? $\left.{ }^{3}\right)$.

Zulke inzigten, bewijzen van zóó ruimen blik, had men, na onze allereerste kritiek, wellig't niet verwacht! Toch zijn ze waarlijk niet de eenige. En ook van uitnemende waarnemingen en niet minder juiste waarderingen van hunne beteekenis hebben wij voorbeelden genoeg. Ik zou u van ARISTOTELES' kennis der Cephalopoden willen verhalen '); het schijnt, dat zij eene soort van "specialiteit" van hem waren - gelijk onze moderne onderzoekers humne lievelingsstudiën (en soms ook wel eens hunne éénzijdigheden) plegen te noemen — indien ik niet prijs stelde op uw oordeel, "dat ik ten minste de verdienste had, van liort te zijn geweest"!

Ik zou u 'er op wijzen, hoeveel voortrefielijls er is in de verhandeling over de roortplanting vooral! Moeten wij niet erkennen, dat ARistoteless de ontwikkeling van het kuiken in het ei met eene voor zijnen tijd en zijne hulpmiddelen verwonderlijke naauwkeurigheid gadegeslaren heeft. Zijn zijne waarnemingen omtrent de eigenaardige plaatsing' van het Cephalopoden-embryo en vooral zijne waardéring van het waargenomen feit niet in der daad verbazend ? ${ }^{5}$ )

Zijn niet de zoogrenoemde "placentale visschen", eerst in 1840 door de onderzoekingen van JoHANnes müLLER nader beliend geworden, door hem ontdekt? Had hij niet reeds kennis van de opvolgende ontwikkeling der organen, en wordt de bekende leer der epigenese niet reeds door hem uiteengezet? ${ }^{0}$ ) En ook, al meenen we Lewes úngelijk te moeten 
greven, waar hij in Arsstotbles' opvattingen aangaande de werking van het zaadvocht de hypothese van BISSChorf wil blijven terugvinden aangaande het tot stand komen van eene katalytische werking ${ }^{7}$ ); heeft hij daarentegen de hoofdzaken van het zoo merkwaardig voedingsverband van moeder en vrucht (bijzonderheden daargelaten, waarvan hij bovendien een deel niet waarnemen kón) niet met verwonderlijke juistheid beschreven? Zijne overal doorschemerende opvattingen aangaande spontane generatie verwijte men hem niet! Een ounoemelijk aantal waarnemingren zijn van noode geweest, om die voor de mag't der feiten te doen terug'wijken, en nog is het niet dan stap voor stap geschied! Wordt de leer der. autogrenese niet thans nom verdedigd, en moet het niet - met LEYDIG b. v. - worden erkend, dat haar a-priori te verwerpen, gelijk het niet zelden wordt gedaan, minstens ongeraden schijnt?

Eene belangrrijke vraag, door de 11 bekende uitspraak van cuvier als uitgelokt, is het nog, of en in hoeverre ARISTOTELEs aanspraak maken kan op den naam van grondlegrger eener wetenschappelijke verdeeling des dierenrijlis. Hare beantwoording levert niet gering'e moeijelijkheden op; vooral, omdat de waarde van een groed deel der door hem aangenomen groepen niet zal kumnen worden bepaald, vóor men omtrent de beteckenis zijner benaming'en voldoende zekerheid heeft verkregren; en hiervan is het op het oogenblik nog verre af.

Voor zoover men echter thans een oordeel hebben mag, schijnt mij de opmerking van LEwes g'eg'rond, dat, indien 'er' in de werken van Anstoteles van eon bepard stelsel sprake ware, dit ongetwijfeld door 
navolgers als ALBERTUS MAGNUS, GRSNER en anderen niet zou zijn onopgemerkt grelaten. Zij hebben in de geschriften van hunnen meester green systeem gezien; wat zou óns verpligten, daarin een systeem te zoeken?! En de zoo uiteenloopende grevoelens van verschillende schrijvers, - ons door BONA MEIJEn in zijn bekend geschrift over de dierkunde van ARISToTELEs uiteengezet — kunnen wel niet nalaten, onzen twijfel grootelijks te versterken. 'Te meer, waar juist diegenen onder hen, die zich, zonder rhetorische overdrijving, lieten leiden door eene zorgrvuldige kritiek (wij noemen slechts WHEwELL en AGsssiz) tot het resultaat worden grebrag't, dat in de werken van ARISTOTELES (ik gebruik de eig'en woorden van laatstgenoemden schrijver) »een systeem, eenige classificatie, of eenig schema (framework) voor de verdeeling van het dierenrijk in grootere of kleinere groepen, ten éénemale wordt gemist" ${ }^{8}$ ).

In der daad is het geenzins een bewijs, dat ArisTOTELEs zich een systeem zou hebben samengesteld, indien het ons ook al, in 't bezit onzer tegenwoordige kennis, grelukken mag', door het bijeenverzamelen en tegenover elkander stellen van de door hem aangenomen groepen, te greraken tot eenig systeem. Juist dit is al te veel geschied, en men heeft hier evenzeer als elders (wij komen er aanstonds op terug')-. om de juiste uitdrukling van LEwes te gebruiken in de schriften van aristoteles de liennis van den nieuweren tijd "ingelezen." En het vergaat ons, dat doende, niet anders dan " den alchimist, die met groote verrukking in zijne smeltkroes het edel metaal terugrindt, door hemzelven onbewust daarin grebragt." 
'Toch mog'en wij, naar ik meen, aan MEIJER toegeven, dat ten minste een negrental wel onderscheiden groepen in de geschriften van aristoteles telkens terugkeeren, die ondanks menige onnaauwkeurigheid of beter misschien onvolledigheid - het doorslaand bewijs leveren voor de ongemeene scherpte van zịnen blik. Maar alleen door den laatsten heeft hij bij het opstellen zijner diergroepen zich laten leiden. In het $\operatorname{oog}^{\prime}$ vallende natuurlijlie verwantschap ontging hem niet, en hij heeft zich daarvan tot ziju doel bediend (op gelijke wijze als hij gebruik maakt van soortgelijke uitdrukking'en uit het dagrelijksch leven ontleend) zonder echter opzettelijh naar dergelijke verwantschappen te zoeken: het laatste ware hem tot het vormen van een stelsel onontbeerlijk greweest. Kenmerkend is het echter, hoe al de groepen van. aristoteles ten duidelijkste blijken, langs den weg der inductie gevormd te zijn (en de allereerste sporen van klassificatie hebben immers altoos dat karakter - gelijk SCHLEIDEN zoo juist heeft opgemerkt -) en tegren den eenigen weg om te geraken tot een begin van een systeem, reeds getuigende van eene hoogere ontwikkeling - den analytischen - trekt hij te velde. De dichotomie valt hij aan, en wijst er op, dat al de moeijelijkheden, waarin zij ons brengen kan, worden vermeden, zoodra men ophoudt, tot grondslag zijner verdeeling zich te bedienen van slechts één enkel kenmerk. En mog'en 'er al een aantal plaatsen zijn te vinden ${ }^{2}$ ), waarin "het niet mog'elijk is, het strenge bewustzijn der noodzakelijlie beginselen eener klassificatie en de sporen eener poging tot verdecling te miskennen"; te beweren, dat el bij Anistotwels aan 
eene behoorligk volgehouden natuurlijlie rerdecling kan worden gedacht, zou, bij het hem volkomen ontbreken der daarvoor noodig'e grondslag'en, met reg't belagchelijk zijn!

Maar men vergete niet, dat ARISTOTELEs zelf met het gebruik zijner groepen eene g'ansch andere bedoeling heeft gehad. Met reden heeft reeds cuvien 'er op gewezen, dat men de Historia animalium met zeker vooroordeel heeft opgevat, meenende, daarin een systematisch leerboek aan te zullen treffen, van grelijke geaardheid, als die wij thans bezitten; terwijl, brij een physiologische verdeeling van het onderwerp, van de behandeling van afzonderlijke dieren alleen als voorbeelden roor de uitgesproken algemeene stellingen lion sprake zijn. "En onder dat vooroordeel liggrende" - zeg't BONA MEIJER - "kon ARisTOTELES evenmin bevredigen, als BERGMANN en LEUCKART's analomisch-physiologische Uebersicht des Thierreichs hem bevredigen zou, die een boek als VAN DER HOEven's, Handboek der Dierkunde had verwacht."

In zijne ware beteekenis beschouwd - en waarom niet, gelijk MEIJER dit doet, met een werk als het zoo straks genoemde vergeleken — zal de Historic Animalium in de eerste plaats blijken, in greenen deele LEwes' benaming te verdienen: eene opeenhooping van daadzaken, zonder regel bijeengebragt eene beschouwing, trouwens reeds vóó hem door ARTEDI en RÉAUnur nitgesproken. Want altoos worden in de verschillende hoofdstukken de dieren in zekere, telkens terugkeerende, volgorde doorloopen; eene volgorde, natuurlijli gewijzigd naarmate dit tot toelichting der behandelde physiolowische stoffe wordt gevorderd; soms worden de redenen aangegreven, 
waarom aan deze of gene opvolging bij de behandeling de voorkeur gegreven werd; en de afwijkingen van dezen regel zijn, mogelijke verminkingen en soms klaarblijkelijke verwarringen in den text nog daargelaten, in greenen deele talrijk genoeg, om de strekking te doen uit het $00 g^{\circ}$ verliezen. Ook cen oppervlakkig doorloopen van den hoofdinhoud der drie meest belangrijke zoölogische schriften van Aristoteles kan ons van de waarheid van het gezegde overtuigen.

Maar aan den anderen kant lian diezelfde vergelijking dienstbaar worden gemaakt, om te doen uitliomen, welke waarde aan de door Aristoteles aangenomen groepen behoort te worden grehecht. Evenmin als wij aan een systeem zouden denken, wanneer (het is een roorbeeld aan MEIJER ontleend) JOHANNES MüLLER in zijne voorlezing over vergelijkende ontleedkunde, zonder meer, " dieren met éénen", en "dieren met twee gewichtsknobbels aan het achterhoofd" teg'enover elkander stelt; evenmin behoeven wij in ARIStoteles' " eijerleggende of levendbarende", "loopende en zwemmende dieren" de hoofdgroepen te zien van cen systeem. En in zijne uitdrukkingen

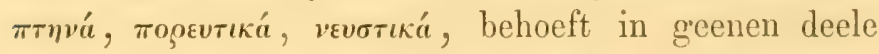
hoogere beteekenis te worden gezocht, dan men in betignann en Leuckart's " laufende, gehende, fliegrende und flugfähige 'Thiere" heeft willen zien.

Indien derhalve van een consequent volgehouden stelsel bij ARistoteles geeń sprake wezen lian, men kan evenmin bij hem de grondslag'en daarvan vinden, als hij vaste benamingen bezat voor den loogeren of lageren rang zijner groepen, aan onze klassen, orden, enz. beantwoordende - indien ' $\mathrm{er}$ 
zelfs onder de door hem aangenomen groepen zijn, waarvan het roornaamste kenmerk aan ARISTOTELES onbekend is gebleven, terwijl alleen veel minder in het wezen der zaak ingrijpende karakters hem ten grondslag zijner verdeeling hebben gestrekt, -- de behoefte aan een natuurlijk stelsel is door hem gevoeld, en de grondslagen daarvoor zijn met juistheid door hem aangegreven; de groepen, waarvan hij zich bediende bij de behandeling zijner alg'emeene physiologie, heeft hij gekozen met zóóveel juistheid en tact, dat zij geruimen tijd als grondslagen van klassificatie hebben g'ediend, en nog in onze tegenwoordige stelsels hunne sporen hebben achtergelaten. Welnu, zou aristoteles den overdreven lof van sommigen behoeven, die ook onze stelsels willen terugrinden bij hem?

Niets is in der daad zonderlinger, dan de ijver en het vooroordeel, waarmede men voor den ouden wijsgeer de prioriteit tracht te verwerven, zelfs van de meest verrassende ontdekkingen der nieuwere wetenschap. Ilk zal de eerste zijn, om te bekennen, dat vaak de uiterste voorzigtigheid wordt vereischt, om niet oneindig meer in aristoteles te lezen, dan hij in zijne woorden heeft grelegd: ik heb die zelf gevoeld, en zelfs nadat il voor mijzelven was gekomen tot het eindbesluit, hetoeen ik u zoo aanstonds uiteenzetten zal, heeft mij vaak de vrees bckropen, dat ik mij toch nog in enkele punten misleiden liet.

Wanneer wij in de verhandeling over de voortplanting lezen - en deze plaats slaat terug op eene andere in de Historia animalium - »door de aderen nu en de overal voorhanden lianalen dringen de voedende stoffen naar buiten, evenals het water door 
ruwe (onverglaasde) aarden vaten, en worden tot vleesch en hetgeen daaraan beantwoordt," hebben wij in der daad eenige moeite, het denkbeeld, dat hier van onze osmose sprake is, van ons te zetten ${ }^{10}$ ).

En wat zal men, bij den eersten oogropslag', zeggen van het volgende:

"Zoolang' het bloed in het ligchaam is, is het warm en vloeibaar; buiten het ligchaam stolt het, uitgenomen dat van het hert en het damhert en van eenige soortg'elijke dieren" - het laatste eene onjuiste beperking, die waarschijnlijk uit het onderzoek van een gejaagd voorwerp, waarvan het bloed in der daad gezeg'd wordt, niet meer te coäguleren) moet worden verklaard. "Het bloed der overige dieren, — zoo vervolgt ARISTOTELES - stolt, tenzij men het van de vezelen ( ( stelling bijkans wordt aan MALPIGHius en BorELLI de eer hunner ontdeklingen op nieuw gregund, als het blijkt, dat ook pLATo reeds spreekt van vezelen in het bloed, maar welke dienen tot voortbeweging daarvan $\left.{ }^{11}\right)$.

Men hęeft zich in deze beide grevallen niet laten misleiden door den schijn. In anderen is men intusschen nog vrij wat verder g'egaan.

De woorden: "de beenderen hangen allen met elkander samen en zijn met elliander verbonden evenals de vaten: een op zichzelf staand been is niet voorhanden." (Men weet, dat hierop door het tongbeen eene uitzondering wordt gemaakt.) "De grondslag bij allen, die beenderen hebben, is de wervelkolom," - die woorden heeft men tot eene anticipatie van de wervel-theorie gemaakt.

$J a$, wanneer in de verhandeling w de generatione" 
het volgende wordt grezegd: "De dieren en de planten ontstaan in de aarde en in de vochtigheid, omdat in de aarde water voorhanden is, en in het water lucht, terwijl in alle lucht levenswarmte voorhanden is, zoodat a. h. w. alles vol is van leven. Daarom worden weldra ligchamen gevormd, zoodra zij (de lucht nl.) in eene enge ruinte ingesloten wordt, en dit greschiedt, doordat zich bij de verwarming der vloeistof eene soort van schuim-achtige blaas vormt" wamneer AUBERT en wiMner dit hebben gelezen, geraken zij in opgewondenheid, en schrijven in eene noot onder hunnen text, dat zij onze "cel" in ArIsToteles hebben teruggevonden.

Ware dát zoo, dan zou men welligt ook IDELER gelijk moeten geven, die hem houdt voor den schepper der undulatie-theorie, omdat hij de licht-voortbrenging met het ontstaan van het geluid vergelijlit. En waarom dan niet meteen met sciweiggen b. $r$. in de mythe der Dioscuren de bekendheid met onze beide electriciteiten geezien?!

Doch dit zijn uitersten. Niemand, die ze op den duur gelooft. Andere dergelijke anticipaties echter worden nog' aangenomen, en g'aan van het eene geschrift over in het andere, totdat ze bijna burgerregt verkregen hebhen in de wetenschap; toch zijn die voorstellingen niet zelden in den grond niet minder valsch!

Nog altoos vinden wij bij de natuurlij]ke geschiedenis der Cephalopoden herhaald (men vergelijke b. v. de opgaven van risgristein in eene der laatst verschenen afleveringen van het handboek van BnoNx), dat die in geheel het dieremrijk op zichzelve staande wijze van bevruchting, waaraan wij gewoon zijn, 
den naam van Heclocotylie te geven, door aristotruts werd grekend. 'Toch wordt uit de andachtige lezing' zijner geschriften duidelijk, niet alleen, dat de waarheid van het verhaal der toenmalige visschers, voor wie de zaak greenzins een geheim was gebleven, door hem werd in twijfel getrokken; maar zelfs spreekt hij als zijne eigen meening uit, dat de paring der Céphalopoden op eene greheel andere wijze greschiedt ${ }^{12}$ ).

Ziedaar eene waarneming, die, als zoodanig, grootendeels binnen aristotELEs' bereik g'eleg'en heeft. Geheel anders wordt het, wanneer hem de leer der zoogenoemde Parthenogenese, d. w. z. van de ontwikkeling van eijeren zonder voorafgegane bevruchting - eene schijnbare uitzondering op de algemeen erliende bevruchtingsleer, waarvan de beteekenis tot dusver niet kan worden verklaard - wordt in den mond gelegd. Moge hij met nog zoo vele bijzonderheden van de verwonderlijke huishouding der bijën zijn bekend geweest; dat hij zich van de raadselachtige verschijnselen, door de zooeven genoemde theorie verklaard, op geheel andere wijze heeft rekenschap gegeven, blijkt uit zijne verklaring: " op gelijke wijze als bij vele(?) visschen jongen worden voortgrebragt zonder vooraforegane paring, schijnt dit volgens de waarnemingen te gebeuren bij de bijën." De bedoelde visschen nu zijn uit de berigten van Anisтoteles ten deele grebleken, hermaphrodieten te zijn; bij de overigen heeft hij aan spontane generatie geloofd. 'Zoodanige pogring tot verklaring' kan van ARstoteles worden verwacht; maar het is het wezen dezer groote ontdekking en de zeldzaam moeijelijke onderzoekingen van voN sreboLd, LEUCкавт e. a. miskennen, wanneer men verder gaat 
dan de uitspraak van eerstgenoemden, met welke wij alle reden hebben in te stemmen, ndat, wanneer door anistoteles had kunnen worden beschikt over de ontdekkingen, waarvan hijzelf verklaarde, dat ze hem ontbraken tot het geven eener behoorlijke rerklaring, niet onwaarschijnlijk ook het geheim der parthenogenese door hem zou zijn doorzien."

In de meening van Lewes, dat ook de eerste waarneming der zoo even genoemde hermaphroditische visschen, niet vóór 1856 , door duFossé, zoowel anatomisch als experimenteel tot zekerheid verheven, "aan aristoteles behoort te worden ontzegd, kan ik niet deelen. Zijne uitspraken daarover zijn niet onduidelijk. Dat hij tot zijn besluit gekomen is, niet zoozeer door directe waarneming der bevruchting of door de anwijzing ook ran de mannelijke sexuële organen, dan wel door eene ran die gelukkige gissingen, waardoor hij ons meer dan eens verbaast, kan aan het feit der anticipatie, als zoodanig, green afbrenk doen.

Maar wél moet met Lewes worden erliend, hoe vooral hier het gevaar dreigt, waarop reeds boven werd gewezen: dat wij, de waarde van ARistotelis' ontdekkingen afmetende, niet van het standpunt der liennis van zijnen tijd, maar van den onzen, die waarde in niet geringe mate overdrijven. Hiervan voorbeelden aan te halen, zou voorzeker overbodig zijn.

Ik moet besluiten. Laat mij dat doen met de poging, uit de u voorgelegrde beschouwingen te liomen tot een eindbesluit. 
1. De wanmeming tan Amistoteles is ons gebleken, in vele grevallen te g'etuigen van buitengewoon talent; maar in zeer vele gevallen ook blijkt zij oppervlakkig, onnaauwlieurig' en zonder kritiek. En de meeste scherpzinnigheid kan de bijna doorgaande overijling in zijne besluiten greenzins vergoêlijken.

Toch is hij, meer dan één zijner tijdgenooten en in dezen zelfs het meerendeel zijner navolgers g'edurende verscheidene eeuwen rooruit -- in hoog'e mate ontvankelijk geweest voor de beteekenis ran de methode der inductie, die in zijnen tijd voor hare mededingster, de schijnbaar meer belovende subjectieve methode heeft moeten onderdoen. Met zijne gewone g’emalikelijkheid heeft hij de eischen van de methode der incluctie niteengezet, en haar aangeprezen, zonder zelf haar in de toepassing getrouw te zijn.

2. Zijne ontleedlunde, rijne vergelijkende ontleedkunde vooral, en niet minder zijne biologische beschouwingen lijden in hooge mate aan de grewone fouten van het onderzoek van zijnen tijd.

Maar de menigte der waargenomen feiten, de buitengewone juistheid van een aantal zijner waarnemingen kunnen g'eenzins worden ontlend, en zijn ruime blik ook op betgeen voor de ontwikkeling der wetenschap werd geëischt, hebben hem gezigtspunten doen openen, warrvan de waarde rerheren is boven allen lof.

3. Het is hem, in zijne ons beliende werken, nimmer om het samenstellen van een systeem te doen geweest, al heeft hij de behoefte daaraan gevoeld. 
Maar zijn scherpe blik deed hem niet zelden samenvoegen, wat uit de natumlijke verwantschap bijeenbehoort, en als zoodanig in onze stelsels ook thans nog wordt teruggevonden.

4. Slechts zelden heeft hij ontdekkingen, tot onzen tijd behoorende, in de volle beteekenis des woords geanticipeerd.

Maar het is onnoodig, daarin de waarde te zoeken van een' man, die bij zijne ware grootheid aan deze overschatting zijner verdiensten greenerlei behoefte heeft.

Wie de waarde van ARistoteles wil voelen, die stelle hem, met geene andere middelen bijlians, dan zijne aangeboren scherpzinnigheid en zijn genie, naast ónze waarnemers, en hetgeen deze, toegrerust met zoo volliomen hulpmiddelen als wij ze thans bezitten, bouwende op den grondslag, door eeuwen vóór ons gelegod, aan de wetenschap hebben toegrebragt; of, beter nog', hij worde met purnius vergeleken!

Maar men vergete daarbij niet, hoe ook AristoTELes het aan zichzelven heeft bewezen, dat de moeijelijke kunst der waarneming moet worden aangeleerd en in den loop der tijden slechts langzaam zich ontwiklielt. Dan zal men, wel verre van den grooten wijsgeer te ruklien uit zijnen tijd, om voor hem eene zoogenaamde absolute beteekenis te zoeken, hem bij zijne waardeering terugbreng'en in dien tijd; en het valsche inzien van uitspraken, als b. v. die van LEVES, dat "de Historia animalium evenmin een gedenkteeken der naturrwetenschap is, als eene leemen hut eene proeve van architectuur." Beide hebben hunne betrekkelijke warde gehad, en alleen als zoodanig historische beteelienis. 
Dan alleen kan tevens een einde komen aan de orerdrijving, waardoor in de ontwikkeling der wetenschap na Aristoteles cen teruggang scheen te zijn ontstaan, zóó groot, dat het altoos onmog'elijli zou gebleven zijn, duarvoor eene voldoende verklaring te vinden.

Naar mijne krachten heb ik thans voldaan aan de verpligting, mij opgelegd door het gebruik; laat mij de gelegenheid niet verzuimen, mij daardoor tevens gegeven, van deze plaats een enkel woord te rigten

Allereerst tot U, Edelgrootachtbare Heeren, Curatoren dezer Hoogeschool! Anistoteles' lievelingsstudie is in den loop der tijden aangegroeid tot eene onmetelijke wetenschap. Geen menschenleven, geen genie als dat van ARistoteles zelven, dat haar nog omvat: een klein onderdeel is al, wat met inspanning van alle krachten geheel kan worden gekend. Behoef ik, op Uwe vereerende voordrag't door' 's Konings keuze groepen, haar aan Uwe Academie te onderwijzen, U te verzekeren, dat ik - op een' leeftijd als de mijne - oprie tegen mijne zware taak? Vergunt mij liever, U openlijk te danken, dat Gij mij de gelegenheid gegeven hebt, van mu aan reeds mijn leren te wijden aan het oneindig schoone, mar ook in practische bezwaren zoo rijke, 
vak mijner keuze. En ik belove U, dát zal ik doen! - Ils weet het reeds, Gij wilt mij daarbij helpen. Voor Uwe magtige ondersteuning bij mijn werk _-. ik zal ze vaak behoeven - beveel ik mij dringend aan. Met haar durf ik hopen op eene niet onvruchtbare werkzaamheid - voor het Onderwijs, voor (ik mag haar nu zoo noemen) ónze Hoogeschool.

Hoogrelcerde Heeren Professoren! Al zou de groote en mij onvergetelijke welwillendheid, waarmede de Docenten onzer Polytechnische School mij, den tijdelijken lecraar, in hun midden opgenomen hebben, mij bijkans tot meerdere vrijmoedigheid hebben verleid - ik kan het mij nog' maar niet voorstellen, dat ik voortaan Uw ambtgenoot zal zijn. En ik zal eenigen tijd behoeven, om mij gemeenzaam te maken met het denkbeeld, aan mannen van Uwe beteekenis in rang to zijn gclijligesteld zelfs ondanks de ontrang'st, mij van sommigen Uwer reeds ten deel gevallen. Vergunt mij, dat ik mij dringend aanbevele in $\mathrm{U}$ aller welwillendheid!

Gij vooral, Hooglecraren der Faculteit, waartoe ik de eer zal hebhen te behooren. Raad en steun zal ik vaak van $\mathrm{U}$ moeten vragen: mag ik vertrouwen, dat Ge mij die nooit onthouden zult?

En aan wien zou ik daarbij eerder denken dan aan U, Hoogreleerde MuLder! Een mijner beste oudere Vrienden - de Nan, aan wien ik de rigting mijner studie dank - schreef mij na mijne benoeming: "Ik wensch u geluk met de onderscheiding, die $u$ te beurt mogt vallen, den waardigen CL. MULDER op te volgen." Toen was ik U persoonlijk onbekend. Nú hebt Ge mij de hoop gereven, dat ik in $\mathrm{U}$ een' vaderlijlicn Frieud zal mogen vinden. IVil 
de betuiging van mij aannemen, dat het mijn innigre wensch is, Uwe vriendschap altoos te zullen waardig zijn!

Gij hebt ons de toezeg'ging . Uwer blijvende werkzaamheid gedaan, en ik twijfel niet, of ze zal U mogelijk en aangenaam worden gremaakt. Het is mijn hartelijke wensch, dat $\mathrm{Gij}$ nog lange jaren voor de Wetenschap moogt blijven gespaard, en dat ook de werkzaamheid Uwer welverdiende ruste rijke vruchten dragen mag!

Eene schaduw is 'er over al mijn geeluk, als ik bedenk, wat deze dag mijn' lieven Vader zou zịn geweest! Reeds vór acht jaren ontviel mij zijn steun; de toen greslagen wonde is sinds nimmer genezen. En zij zal het ook niet!

Maar dat ik dan ten minste hier het woord had mogen rigten tot $U$, Hooggeleerde vaN DER HOEven, en van deze plaats $U$ mogen danken - al zal ik liet nimmer genoeg kunnen doen - voor zooveel, wat ik aan $U$ ben verpligt. Och, of ik de eer, de leerling te zijn van een' Han, wiens naam overal, waar de dierkunde hare beoefenaars telt, met groote eere wordt genoemd, niet onwaardig blijken mog't! Niet onwaardig ooli de vriendschap en de ondersteuning Uwer buitengewone kennis, die Gij mij altoos greschonken hebt!

De in dit jaargetijde in der daad verre reize heeft ook U teruggehouden, hier tegrenwoordig te zijn, hooggelcerde harting! Gij weet het, indien er iets goeds uit mij mogt voortkomen, heb ik het te danlien aan VAN DER HOEven en aan U. Wees overtuign, dat ik Uw nitnemend onderwijs, Uwe onuitputtelijke hulpvaardigheid nimmer vergeten zal. En 
blijf ook Gij mijner met belangstelling gedenken! Een hartelijke groet uit de verte en een woord van dank en aanbeveling ook aan $U$, waarde en hoog reachte COHEN stuart, die mij mijn liort verblijf aan de School, waarvoor de zorg aan U is opg’edrag'en, met uwe aanmoediging, met uwen raad, met uwe trouwe vriendschap in waarheid onverg'etelijk hebt gremaakt! En niet minder aan U, waarde voGELSANG! Ik heb in den korten tijd van onzen vriendschappelijken omgang uwe buiteng'ewone talenten, uwe grelukkige ontwikkeling, uw helderen blik, uw vurigen zin voor waarachtige natuurwetenschap te zeer leeren waarderen, dan dat ik mij zou verhelen, hoe ik uwen omgang missen zal. Mogen wij, elk naar zijne krachten, werkende in denzelfuen geest, elkander op onzen verderen weg regt vaak ontmoeten!

En thans een woord tot U, WelEdele heeren Studenten aan deze Hoogeschool! Of mijne werkzaamheid vruchten zal dragen, een goed deel daarvan zal - bij mijne beste pogingen - af hangen van U. Ik weet niet, hoe Ge mij ontvangen zult: ik weet het niet, of 'er welligt onder $U$ worden g'evonden, die mijn werk zullen beschouwen met vooringrenomenheid, omdat zij - uit welke beweegreden dan ook aan een' ander de voorkeur hadden g'eg'even boven mij; anderen misschien, geneigd, mij een verwijt te maken van mijnen leeftijd, en mijne (waarom $U$ verheeld, wat Ge allen nagaan kunt?) nog zeer g'eringe ervaring. Voor zoover ik echter de studenten ken (en Ge weet, het is nog zoo lang niet, dat ik óók tot hen behoorde) hebben ze ruimer begrippen. 'Toch verbeid ik met spanning' de verhouding', dic 
'er tusschen ons zal bestaan; want - ik herhaal het $U$ - daarvan hangt alles af! Indien ik mij verstouten mogt, $U$ te wijzen op mijne voormalige toehoorders, aan wie Ge - ik geloof op grond eener tweejarige ervaring waarlijk ten onreg'te - den naam van "studenten" hcht ontzegd, ik zou u willen vrag'en: „Ontvangt mij, en doet met mij als zij hebben gedaan. Maar doet in één ding beter!" - Valt elkander toch niet hard, wanneer Ge - het wordt, helaas! te veel verzuimd - ook buiten de voorgeschreven lessen en op vrijer wijze dan daar mogrelijk is, tot mij komt om te raadplegen, om samen te werken. Ziet, dát wil ik met U komen doen! Ili roel — aan het begin mijner academische loopbaan -- hoe onze prUIJs vaN DER HOEvEN (wiens laatste boek in $\mathrm{U}$ aller handen behoorde te zijn!) aan het einde daarvan kon schrijven: " Ik moet het, helaas! bekennen, ik ben met de rol van docent zoo weinig ingenomen, dat ik zooveel mog'elijk getracht heb, de rol van student voort te spelen en ik mij in mijn emeritaat vooral daarom behagelijk voel, omdat ik nu wederom eenvoudig student kan zijn, zonder te moeten doceren." Het is aan U, te zorgen, dat ik student blijven kán! Spreekt vrij Uwe meening tegen mij uit, en vooral, laat mij weten, wat Gij anders wenschen zoudt. Uit dat oogrpunt heb ik reeds in der tijd de verschijning van Uwen "Vox" met belangsstelling begroet; mar Gij kunt ook van mond tot mond met mij spreken. Wat mij betreft, ik zal het $\mathrm{U}$ toonen, dat ik de leuze van Uw orgalan overgenomen heb: "Thu res agitur!" 'I'e samen willen wij genieten van de aaubiddelijke selioonheid der Naturu, te samen haar onderzocken 
en ons rerblijden in haten oniitputtelijken rijkidom, te samen haar liefhebben, zóo als ze dat verdient. En - want ook dat zullen wij te samen ondervinden - waar de Tijd en de reusachtige vooruitgang onzer Wetenschap hoe langer hoe meer van onze krachten komen vergen, zullen onze vereende krachten doen, wat zonder deze samenwerking meer en meer onmogelijk wordt.

Dat niemand Uwer - dat niemand van ons allen — vertrag'e, maar werke, zoolang het dag is. Want om te werken zijn wij hier.

"Wél hem, die niet moede wordt!"

IK HEB GEZEGD.

l'ag. 1, ondurste regel, stuat: des gezags verbreken.

moet zijn: des gezags worden verbroken.

23 , reg. 10 v. 0. , staat: plaatsing van het Cephalopoden-embrjo inoet zijn: plaatsing van den dojer bij bet Cephalopoden-embryo. 



\section{AANTEEKENING.}

') l'a.r. 18. T'erwijl bij de schrijvers sóór AnIstoteles de zenuwen als zoodanig schijnen onbekend geweest te zijn, vinden wij door dezen in der daad van die deelen gewag gemaakt. Ilet drietal hersenzenuwen crenwel, warvan het algemeen verloop door hem is angegeren, wordt

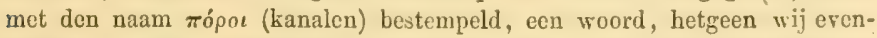
zeer b. v. voor bloedvaten, voor den ureter, voor de vasa deferentia, enz. gebruikt vinden. En zijne uitdrukking, dat deze $\pi$ ópo tot de voe-

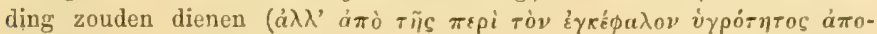

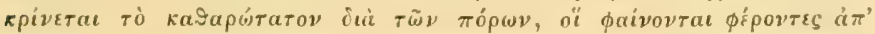

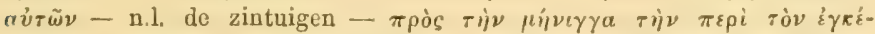
$\phi a \lambda o v$ - de generatione II, $\S 97-$ ), sluit de mogelijkheid, dat hij met de beteekenis dezer deelen als "zenuwen" bekend zij geweest, uit.

En dat ook, wat door ons onder nzenuwstelsel" wordt verstaan, aan Aurstoreles volstrekt onbekend is geweest, blijkt 0 , a. hieruit, dat het ruggemerg door hem gehouden wordt voor het merg van de wervelkolom, de laatste a.h.w. als een groot pijpbeen beschouwd; (vgl. de partibus, II, cap. 6; waaruit intussehen ook blijken zal, dat het groote versehil van dit merg met het elders voorkomende, geenzins door Anrstoteles onopgemerkt gebleven is. - Zie ook de eerste regels over de hersenen in cap. 7: nterwijl de hersenen dienen, zoowel tot compensatie van de uarmte van het ruggemerg als van het hart en zijne omgeving; on het feit, dat de hersenen gevoelloos zijn, zoowel als de onmiddelijke waarneming bewijzen, dat zij met de gevoelende deelen" (het vleesch, 1. c. cap. 8 - ofschoon, gelijk door frustzres in zijne vertaling te regt 


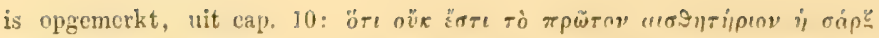

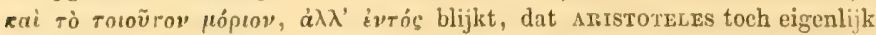
eerst in het vloesch het eigenlijke zintuig des gevoels zocht;) nin geen verband staan." Als centraaldeel "Empfindungsmitte: Sitz der empfinden-

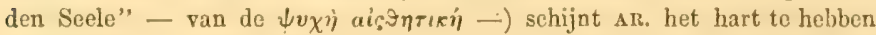
beschouwd; zijne voorstelling echter, b.v. van het verband daarvan met do peripherie, is nict duidelijls. Vgl. 0. a. MEIJER, Aristoteles' 'Thierkunde, pag. 427.

2) Pag. 22. De plaatsen, waarop ik dit schrijvende het oog heb, bevatten in hoofdzaak het volgende:

"De samenstelling ran het dierlijk ligchaam is drieërlei. Tooreerst lkan daarbij aan de samenstelling uit de door sommigen zoogenoemde elementen worden gedacht, als daar zijn: aarde, lucht, water, vuur"..

"De tweede samenstelling nu na die uit de clementen is het ontstaan der gelijksoortige deelen ( van vleesch en van dergelijke." - En in de Historia animalium vinden wij deze gelijksoortige deelen nog nader bepaald als ndiegene, welke wederom in gelijksoortige deelen kunnen worden verdenld, zooals vleesch in stukjens vleesch."

n De derde en laatste samenstelling is die der óngelijksoortige deelen ( $\tau$ ci

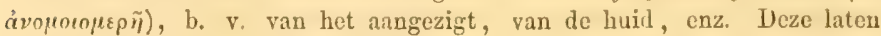
zich nict scheiden in gelijksoortige deelen: de hand kan niet in een aantal handen worden verdeeld."

"En onder deze óngelijksoortige deelen zijn er, die niet enkel als declen worden onderscheiden" - voegt de Historia animalium or bij maar die een geheel vormen, dat wederom zijne eigene declen heeft. De zoodanige deelen noemen wij ledematen." En het hoofd, de arm, de borst worden als voorbeelden aangehaald.

"De deelen der dieren nu zijn uit beiderlei (zoowel uit gelijksoortigc als uit ongelijksoortige deelen) te samengesteld; maar de gelijksoortige zijn ter wille van de ongelijksoortige voorhanden: de laatste toch hebbeu bepaalde verrigtingen, zooals het oog, de neus, en het gansche gelaat, en de vinger en de hand, en de geheele arm"....

" De gelijksoortige declen nu bèzitten elk voor zich ecne of andere eigenschap: het eene is zacht, het andere hard; het eene is vloeibaar, het andere vast; het eene taai, het andere bros; de ongelijksoortige deelen daarentegen bezitten verschillende eigenschappen, en wel met elkander in verband: de hand gebruilit om te drukken eene andere kracht dan om aantevatten.... Daarom bestaan dan ook de verrigtende declen uit beenderen en peezen en vleesch en andere ótoropepï"....

$\mathrm{Na}$ deze uiteenzetting komen - als hadden we een leerboek roor ons uit den tegenwoordigen tijd - achtereenvolgens de gelijksoortige deelen van AIISTOTELES tot behandeling.

$\left.3^{3}\right)$ Pag. 23. Aldaar wordt namelijk geregd: „Bij sommige dieren zijn de deelen van het ééne gelijk aan overeenkomstige declen van het andere; bij andere diereu echter vinden wij ecne dusdanige gelijkheid niet. In de ecrste plaats au kunnen de declen met elkander vergeleken 
worlen, omdat zij denzelfiten vorm hebben: nous, nog, beenderen van een' mensch, van cen paard, gelijken op dezelfde deelen van een ander mensch, van een ander paard.... maar ook kunnen de deelen zich onderscheiden door verschillende eigenschappen, zooals b. v. de lileur; en de eene groep *) bezit van dezelfile hoedanigheid meer, de andere minder. Ook het grooter of kleiner getal, de meerdere of mindere omvang van zeliere deelen leveren punten van verschil: de cene diervorm heeft cene zachtere, de andere eene hardere bekleeding; de eenen hebben ecnen langen snavel, bij anderen is hij kort, enz.... Bij andere dieren eindelijk kan men niet zeggen, dat do deelen dezelfde gedaante hebben, of dat zij van elkander verschillen in het meer of minder, maar de declen zijn aan elkander analoog: zoo is de veder voor den vogel, wat de schub is voor den visch; men kan uit dit ongpunt veêren en schubben aan elkander gelijk stellen, en evenzoo beenderen en graten, nagels en hoeven, de haud en de scharr der kreeft"...

4) Pag. 23. Men vergulijke hier slechts: Außsw's, die Cephalopoden Iles Aristoteles (Sept. - Abdruck aus der Zeitschrift für wissenschaftliche Zoülogie, XII, 3 IIeft), pag. 13 sqq.

De bewering echter op pag. 14: "man unterscheidet jetzt eine ganze Anzahl einzelucr Tnorpel an Kopfe der C'ephalopoden" is echter ónjuist; waarschijnlijk is in plaats van "am Kopfe", am Körper" bedoeld. Vyl. de aldiar aangebaalde Forgl. unatomie van vos sIemold en stavisus

Aldaar pay". 16 en 17 eene zeer karalkteristicke verdediging van Aristoteles' berigten aangaande de "zeil-togtjens" van AmgorautA.

5) Pag. 23. "Zoodra het Sepia-wijfjen" - zegt Aristoter.es - "hare eijeren heeft gelegd, vertoont zich het inwendige in de gedaante van cene lagelkorxel: darruit ontwikkelt zich namelijk de jonge Sepia met den kop diaraan hangonde. De waarneming is, bij eenige onduidelijkheid in de uitdrukkingen, juist, en door süLliser bij zijpe beroende onderzoekingen volkomen berestigd. Maar wat de groote waarde aan deze uitspraak geeft, is de bijvoeging, dat ndit verband te vergelijken is met de wijze, waarop de rogels met den buik aan den dojer bevestigd ziju." - "Wat de beteekenis dezer navelachtige vergroeijing wezen mag" - zoo gaat ARIsTOTELES voort - " is nog niet wargenomen." Dubbel to betreureu is het bij zulke beschouwingen, dat ook hier (met letters, juist zooals wij zelven dit thaus gewoon zijn te doen) naa eene figuur wordt verwezen, die, helaas? gelijk meerlere niet genoeg te betreuren zaken, voor ons is verloren' gegatn.

5) Pag. 23. Gelijk bekend is, laten zich te uiterst monigvuldige

*) Ik heb gencend, hicr geen gebruik te mogen maken van fle termen "geslachu" en "soort", omdat, gelijk nit de lezing van mernes's beschouwingen over dit punt (1 c. pag. $345 \mathrm{sqq}$, 351 sqq., $359 \mathrm{sqq}$.) kan wor-

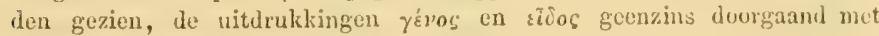
genus en species mogen worlen vertald, man veelecr mechselude licgriffe für die versehiedene Hühe der Ueherordnung" zijn. 
theoriën nver het wezen der voortteling terugbrengen tot cenige hoofdgroepen.

De meeste wijsgeeren der Oudheid schijnen de voorstelling te hebben gedeeld, welke reeds bij de oudste volken wordt teriggevonden, dat de man (of liever het product van diens voorttelings-organen) te vergelijken is met het zaad, de vrouw met den bodem, waarin dat zaad tot ontwikkeling komen zal. De ontdekking der spermatozoïden - alleen, maar dan ook altoos, voorhanden bij dieren, tot bevruchting in staat - scheen den voorstanders dezer theorie zeer te stade te komen. Zonder meer vỏor de werkelijke embryones verklaard, werden ze het voorwerp van de zonderlingste bespiegelingen - waaromtrent in de volgende anteekening een en ander wordt vermeld.

Tegenover deze spermatisten, gelijk men hen heeft genoemd, stelden zich va de ontdekking ook van het zoogdier-ei (of eigenlijk van het aanvankelijk voor bet ei zelf gehouden Graaft"sche blaasjen) anderen, met de bewering, dat het vrouwelijke dier de kiem van het jonge voorwerp levert, en door het mannetjen slechts $a, h$. w. de aanleiding wordt gegeven tot de verdere ontwikkeling.

Beide, spermatisten en ovisten, stonden tegunover de zoogenoemde theorie der syngenese, reeds van Empedocles af komstig, die op grond van de gelijkenis der jonge dieren met beide ouders beweerde, dat het product der beide sexen voor de voortteling gelijk noodzakelijk was.

Die samenwerking nu, waarvan de noodzakelijkheid door latere onderzoekingen is buiten twijfel gesteld, trachtte men op verschillende, in hoofdzaak op tweeërlei wijze te verklaren.

Er waren 'er, die geloofden, dat het embryo in de liem reeds van te voren bevat is, en door de inwerking der bevruchting $a . h$. w. slechts zigtbaar wordt gemaakt; ja, dat zelfs de eerste generatie reeds de kiem van alle opvolgende geslachten zou hebben bevat, die dan alle van lieverlede daaruit werden ontwikkeld.

T'egenover deze evolutic-theorie, in der tijd zelfs voorgestaan door mannen als SWAMERDAM, réAUMUR, TONNET, HALLEle, maar thans verlaten, heeft zich de leer der epigenese gehandhard en met een steeds toenemend aantal embryologische onderzoelingen bewezen, dat eerst van lieverlede na de inwerking van het bevruchtende sperma in het embryo de deelen worden gevormd, die daaraan later zullen worden berkend.

De beschouwingen van Alis'cotrils over dit punt (de generatione, II, \$ 14 sqq.), laten zich in de hoofdzaken - en zooveel mogelijk in zijne eigene bewoordingen - aldus teruggeven :

"Of alle deelen ontstaan te gelijkertijd, óf na clkander: gelijk het in de zoogenoemde gedichten van Orpheus heet, dat het dier op dergelijke wijze wordt gevormd, als de mazen van een net. Dat nu de deelen niet te gelijkertijd ontstaan, kan duidelijk worden waargenomen; want men ziet, dat vele deelen reeds aanwezig zijn, andere cchter nog niet, en er valt niet aan te denken, dat men ze misschien nict zou zien, wijl ze daartoe te klein waren: want ofschoon de longe eenen grooteren omvang heeft dan het hart, vertoont zij zich bij het begin der ontwikleling later dan dit. - Waar nu het ééne deel vroeger, het andere later ontstaat, 
zon worlt het de rraag, of het eene deel het andere vormt, zoodat er tusschen beide afhankelijkheid bestaat, of wel ontstaan de deelen slechts eenvoudig na elkander."

Een lang betoog volgt, waarin de mogelijkheid van het eerste wordt bestreden, en de meening uitgesproken $(\$ 24)$, dat nniet alle deelen te gelijkertijd ontstaan, maar één daarvan het eerste." En "van het ontstaan van dit eerste deel is niet een orgaan de oorzaak, maar datgene, wat van buiten het eerst den aanstont tot beweging gaf."

Met het laatste wordt $(\$ \$ 19-21)$ het sperma bedoeld, hetgees ween

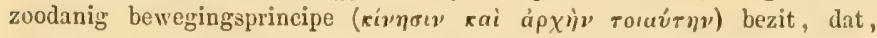
wanneer de aanstoot tot beweging ophoudt, elk der deelen tevens leven

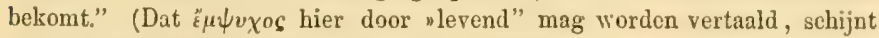
mij uit het verder volgende duidelijk te blijken.)

Het valt, dunkt mij, niet te ontkennen, dat in het bovenstaande de leer der epigenese opgesloten ligt. De volgende plaatsen - ik haal slechts enkele aan - doen zelfs denken an bekendheid met de successieve ontwikkcling, eerst ran algemeene, later van meer specifieke karakters.

De generatione, II, $\$ 35$.

"Want aanvankelijk schijnen alle zoodanige dierfoetus cene soort van plantenleven te leiden; en eerst later is 'er bij hen sprake van de air.

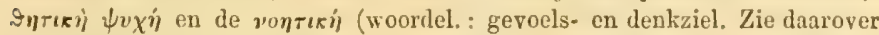
o. a. de inleiding tot AUBERT en WrMMER's vertaling van bovengenoemde rerhandeling, p. 6);

en, ééne \$ vroeger:

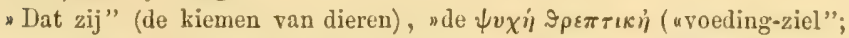
waarom niet $n$ het vegetatieve-levensbeginsel?) bezitten, is duidelijk;... maar gedurende het verder verloop der ontwikkeling moeten zij nog de

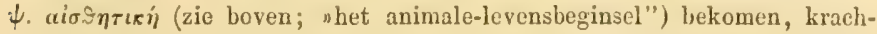
tens welke zij dieren zijn. Want (?) het dier-worden en het menschworden, en het dier-worden en het paard-worden geschiedt niet gelijktijdig; en bij alle andere dieren is het evenzoo; want het einddoel en de - voleindiging worden het laatst tot stand gebragt, en het einddoel der ontwikkeling van alle dieren is hetgeen hen karakteriseert" ( "Als soort" zouden wij 'er willen bijvoegen.

7) Pag. 24. El is misschien geen vraagstuk in de gansche leer van het leven, waardoor meer hypothesen zijn uitgelokt, dan het vraagstuk der bevruchting. Het is bekend, hoe, reeds in 1789 , BLUMexBaci in zijn werkjen wueber den Bildıngstrieb" schrijven lion, dat nDRéLrxcounT alleen uit de schriften zijner voorganger's niet minder dan 262 óngegronde hypothesen bijeen te verzamelen wist, welk getal door hemzelven wederom met één was vermeerderd." - En het is verwonderlijk, hoe men, in tal van bespiegelingen over een voorttelingsvocht, zoowel door het mannelijke, als door het vrouwelijke dier afgescheiden, verdiept, nog in de $17 \mathrm{e}$ eeuw niet verder was gekomen dan tot het denkbeeld (zcer ten onregte door Harvex uit zijne proefnemingen afgeleid), dat het vrouwelijke dier vruchtbare eijeren roortbrengen zou ten gevolge van den invloed, dien het sperma bij de paring op zijn gehecle organisme uitgeocfend had. Eerst spaldanzani zou, tegen het einde der vorige eeuw, 
door zijne uitnemende experimenten het bewijs leveren, dlat, aan den éénen kant, ook zonder voorafgaande bevruchting eijeren kunnen worden gelegd; dat echter die eijeren, zullen ze zich ontwikkelen, in aanraking moeten komen met het mannelijk zaad.

De vraag naar het wezen der berruchting bleef bestaan, maar werd nu deze: Welke is dan de werking van het zaadvocht op het ei? In zijne chemische samenstelling werd niets bijzonders gevonden. Maar het mikroskoop zou daarin eene menigte ligchaampjens aantoonen, in de vloeistof gesuspendeerd, waaraan men (niet zonder voorbarigheid daaraan eene dierlijke natu $1 r$ toeschrijvende) den naam van "animalcula spermatica" of "spermatozoën" gaf.

Door sommigen als infusoriën beschouwd, van een bepaald parasitisch karakter, bleek het uit nieuwe observatiën en proefnemingen, dat deze spermatozoïden, wel verre van aan het organisme rreemd te zijn, of gelijk anderen wéderom meenden - vit de ontbinding van het zaadrocht te zijn ontstaan, de eigenlijke bevruchtende elementen waren. De menigvuldige bespiegelingen over de bevruchtende working eener zoogenaamde naura seminalis" waren met do nieuwe ontdekking, dat die elementen doordrongen in het ei, tevens weêrlegd en de vraag was voortaan deze: welke is de werking der spermatozoilden?

Al schijnt het niet ongewone verhaal, waarin aan DaLexpa'ius de bewering wordt toegedicht, dat hij een spermatozoïd zijne bekleeding zou hebben zien verliezen, en toen zcer duidelijk den vorm van een menschelijk ligchaam vertoonen, met hoofd en ledematen - ónjuist; 'er waren er toch, die meenden, dat zij kleine embryones waren, bestemd, om binnen in het ei tot verdere ontwikkeling te komen. Maar betere onderzoekingen hebben aangetoond, dat die elementen veeleer, nadat zij op het ei de werking hebben uitgeocfend, ten gevolge waarvan zijne ontwilkkeling aanvangen zal, daarin a. h. w. worden opgelost. Wat daarbij eigenlijk gebeurt, is ons tot hicrtoe volkomen onbekend gebleven; en indien men al, met BIsschorF, hierbij aan eene katalytische werking heoft gedacht, heeft men met die uitdrukking zelve erkend, dat het wezen der zaak nict door ons wordt doorgrond.

Men heeft in de schriften van Aristoteuss iets dergelijks willen lezen.

Nadat hij (de generatione, I, \$ 32 sqq.) met eene vrij lange redenering de in zijnen tijd heerschende meening heeft wcêrlegil, dat het zaadvocht uit het geheele ligchaam zou afkomstig zijn, wijst hij (op grond eener onvolledige warneming) als de dcelen, waarin het sperma afgescheiden wordt, niet de testes, maar de vasa deferentia aan. Overgaande tot de beschouwing van het sperma zelf, verklaart hij, daarin eene wbruikbare uitscheiding", elders: "eene, die nog tot wasdom en leven kan worden gebruilt" - eene afscheiding derhalve - te zien, en wel nde onvermengde, meest zuivere af.cheiding, znoals die, als zij niet in den vorm van sperma afgescheiden wordt, naar de wecfscls wordt gevoerd, en hunne voeding en hunnen wasdom bowerlit $\mathrm{Na}$ in der daad allermerkwardigste beschouwingen over de afseheidingen in het algemeen ") stelt AltsrorEIs:

") Wij citeren slechts: 1 . c. 63 : werder is het sperma noch in de 
de vraag: wat eigenlijk dit sperma zij. Zijne werking wordt vergeleken

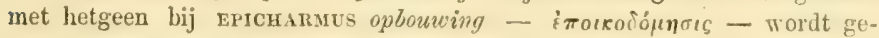
noemd, "gelijk b.v. uit laster smaad, en uit smaad strijd voortkomt, in 't algemeen zóó, dat van ecn eerste let begin der bexieging uitgaat." In het laatsto geval nu ligt het bewegingsprincipe of in de dingen zelven (gelijk in het aangehaalde voorbeeld) of daarbuten (nzooals in de kunsten voor de kunstwerken en in het licht voor het brandende huis"). Tot écn van beide kategoriën nu behoort klaarblijkelijk het sperma: of het is stof voor het wordende, dus passief, óf bewegingsprineipe, derlalve acticf. Het zou echter ook beide kunnen zijn.

Dat 'er echter alleen sprake kan zijn van de in het sperma aanwezige kracht en beweging, volgt zoowel uit de theorie als uit de werkelijkheid; onder andere bewijzen (hij gecft in verscheidene en daaronder ook valsche) vinden wij ook dit: "Zoodra het wijfjen (der eijerleggende visschen) zijne eijeren heeft gelegd, stort het mannetjen zijn sperma daarover uit, en die eijeren, waarop dit valt, worden vruchtbaar, maar de anderen niet. Ontbreekt de aanstoot, in gewone gevallen door het sperma gegeven, zoo is de ontwikkeling nul of onvolkomen.

Aristoteles is echter nog verder gegaan, en zegt (\$88): "Daar het mannetjen den vorm geeft en het principe der beweging, het wijfjen daarentegen het ligchamelijke; de stof, even gelijk bij het stollen der. melk, deze laatste de stof is, maar de leb datgene, waarin het principe is beval, evenzoo werkt hetgeen het mannetjen bijbrengt in het wijfjen."

cerste jeugd, noch in den ouderdom, noch tijdens zware zickten voor" handen: in 't laatste geval uit zwakte; in den ouderdom, wijl de natuur niet meer bij magte is, het voedsel genoegzaam to bewerken - oric ti

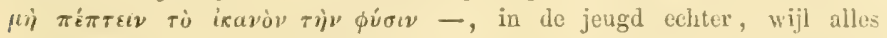
reeds opgebruikt is voor den groei." En vooral \$64: "Zoowel bij de dieren als bij de planten is 'er, wat de productic van sperma betreft, groot verschil, zoowel tusschen de verschillende diersoorten als ook tusschen die, welke tot dezelfde soort behooren; b.v. tusschen den eenen en den anderen mensch of tusschen den eenen en den anderen wijnstok.... Eenigen leveren veel sperma; anderen weinig; nog anderen in 't geheel geen, en dat niet uit zwalite, maar bij cenigen zelfs uit de tegenovergestelde oorzaak. Want wat zaad had moeten worden, is an het ligchaam besteed: vele menschen namelijk storten minder sperma nit, en zijn minder wellustig, wanneer zij corpulent zijn en vecl vleesch of eene grootere hoeveelheil vet aanzetten. Daarmede to vergelijien is het verschijnsel, dat bij de geile wijnstokken voorkomt, die ten gevolge van te overvloedig voedsel overmatig loof maken, op gelijke wijze als de bokken, wannecr zij te vet worden, minder bespringen. Men zockt ze daarom magerder te maken, en noemt zulke wijnstokken naar dit bij de

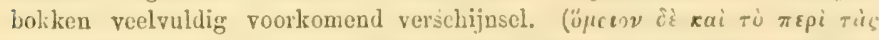

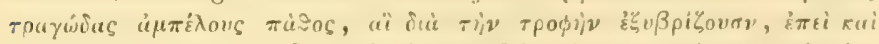
oi тра́)

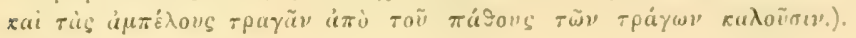




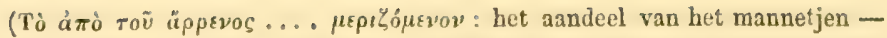
gelijk Prof, van Der roeven de vertaling van aUbert en w IMMER verbetert, die achter het zooeven teruggegevene nog vocgen: nindem $e_{8}$ sich theilt" - eene bijvoeging, waarvan zij zelven waarschijnlijk even weinig den zin hebben verstaan als iemand, die haar leest.)

Wil men inzien, wát hier eigenlijk door AnIstoteles is bedoeld, zoo neme men zijne denkbeelden omtrent de door het vrouwelijk organisme geleverde afscheiding te baat. Het wijfjen der vivipara levert volgens hem geen ei, maar in de katameniën ziet hij eene afscheiding, aan het sperma des mannelijken diers beantwoordende, hoewel a. h. w, van minder

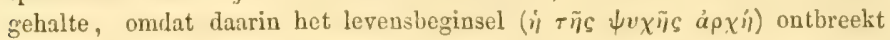
(lib. II, $\$ 40$ ); en die afscheiding is het, welke, terwijl het mannetjen het (actieve) bewegingsprincipe levert, in de (passieve) stof voorziet. En door het vast worden (stollen) van deze vlocistof wordt de aanleg van het embryo geleverd. Of - gelijk Lib. II, \$5.) staat - whet sperma bewerlit een zichsamenvocgen van het zuiverste in de afscheiding van het

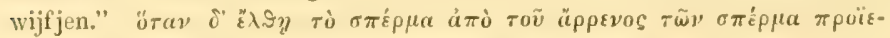

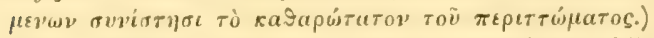

De oorsprong van ARINTOTELEs' vergelijking schijnt mij hiermede voldoende verklaard, om te doen uitkomen, dat zijne theorie met cene hypothese als die van BIsscrofr niet behoort to worden gelijkgested.

8) Pag. 25. Een gelijk oordeel, als hier (uit zijn "Methods of study in natural history." Boston, 1864) werd aangehaald, is door AGAssiz uitgesproken in zijn "Essay on Classification, London 1859, p. 302: "Men kan niet zeggen, dat door Anistoteuis ergens eene geregelde liassificatie is uiteengezet. Voortlurend spreekt hij van meer of minder uitgehreide groepen onder cene gemeenschappelijke bevaming, welke groepen door hem lklaarblijkelijk als natuurlijke afdeelingen worden beschouwd. Nergens echter is door hem de overtuiging uitgesproken, dat deze groepen op zoodanige wijze zouden kunnen gerangschilit worden, dat daardoor de natuurlijke verwantschap teruggegeven werd."

9) Pag. 26. Een aantal plaatsen, die als bewijzen kunnen dienen voor het hior opgemerkte kan men bijeengesteld vinden bij MEIJER, 1. c., pag. 102-106 in het oorspronkelijke - de vertaling pag. 106-110.

10) Pag. 30. Men dient hierbij de geheele opvating van den bloedstroom door Aristoteles in aanmerking te nemen Eene circulatic kent hij niet; en hij meent, dat de vaten, die het gedigereerile ("gekochte", Auß, en win. - Aristoter.es bedient zich steeds van het werkwoord $\pi \dot{\varepsilon} \pi \tau \omega)$ - bloed naar alle ligchanmsdeelen voeren, en daerin eindigen, al dunner en dunner worden, en ten slotte zó naauw, dat het bloel, als zoodanig, daardoor niet meer uitstroomen kan. Tooral verdient de bijvneging onze anndacht, dat nu alleen de uitscheiling van voeht, die: men iôpüra noemt, tot stand komen kan, en dit vooral dan, wannęr het ligchuam warm is , en de vaten zich verder openen." 
1) Pag. 30. De vertaler van de verhandeling over de declen der

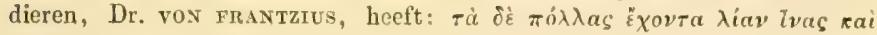
maxeias ... in het op pag. 20 vermelde roorbeeld werlielijk vertaald: ndiejenigen aber, welche zu vielen und zu f:sten Faserstoff haben!!

12) Pag. 32. Het kan niet onnuttio zijn, wanneer de meest gewone zoogenoomde anticipatic van iristotlues, die van de liectocotylie der Cephalopoden, hier nader wordt onderzocht, opdat men zelf kunne nagaan, of en in hoeverre aan onzen wijegeer regt daarop mag, worden tocgokend. - De leer der parthenogenesis acht ik minder noodig, nit dit oogpunt te bespreken, daar hij - gelijk reeds in den text is gezegd - in het wezen dezer zaak niet kán zijn doorgedrongen. Dat ook vos sIEBoL, AnistoTELes niet voor daarmede bekend gehouden heeft, blijkt uit diens "die Purthenogenesis; Vortrag zur Feier des $103^{\text {n }}$ Stiftungstages d. k. Academie in München, 1862. Over artstoteles' in der daad groote kennis van het bijënleven kan men nalezen een opstel van AUBEıT en WmMER, in de Zeitschrift für Wisscuschaftl. Zoölogie, J. $185 \% 8$.

De geschiedenis van do ontdekking der IIectocotylie is in hoofdtrekken de volgende geweest. In het jaar 1825 werd door DELLE CHIAJE op ecne Argonauta (de zoogenoemde pepieren nautilus onzer vaderlandsche verzamelaars) een dier geronden, dat zich daaraan, door middel van op zijn ligchaam aanwezige zuignapjens had vastgehecht, en, na losgemaakt te zijn, vrij in het water rondzwom. DetLe chiase meende dit zonderlinge roorwerp roor eenen ingewandsworm te moeten houden. Vicr jaar later werd door cuvier een dergelijk voorwerp gevonden in eenen Octopus, uit de Middellandsche Zee af komstig. Fn ook hij meende in den Ilectocolylus, gelijk hij het dier heeft genoemd, cen' ingewandsvorm te moeten zien. In 1841 eerst werd door costa een stap nader tot de verklaring gedaan, en het voorwerp - hocwel nog op ónjuiste wijze - met de voortplanting in verband gebragt. En dit denkbceld kreeg meerdere uitbreiding door DUJARDIN, die op goede gronden den Hectocotylus verklaarde, een afgescheurde arm eener Cephalopode to zijn, dic welligt cenige beteekenis voor de bevruchting hebben kon.

Inmiddels had in 1842 KöLLiker te Messina eenen nieuwen Hectocotylus gevonden, en dien beschreven als het zeer afwijkend van het wijfjen gebouwde mannetjen; zelfs meende hij daarin darmkanaal, hart en zeer ontwikkelde generatie-organen te kunnen aanwijzen.

Reeds had zijne meening veclvuldig ingang gevonden, toen rérany ditmaal weder aan ecnen Octopus - de plaats van een' der armen door een eigenaardig blaasvormig deel ingenomen zag, waarbinnen hij evenwel een op een' arm gelijkend, zeer ligtelijk afrallend, orgaan terugvond. IDE FILIPPI herkende in dezen arm den Hectocotylus van cuvier. In dien arm - zoo meende nu vérANY - zouden zich periodick de mannelijke geslachtsorganen ontwikkelen.

Eerst InErлich xüLler zou, in 1850 , de laatste groote dwaling vorbeteren. Hij vond aan het merkwaardige kleine, geene schaal bezittende, mannetjen van Argonazuta cenen hectocotylus-arm, die - gelijk welura door KöLliker bevestigd werd - van uit de op de gewone plaats in 't 
achterlijf voorhanden testes met sperna kon worden gevulil. - Op wat wijze dit laatste echter geschiedt, is tot hiertoe onverklaard gebleven.

Het is waarschijnlijk, dat bij de paring de beide sexen elkander met de armen omvatten, en dat daarbij de met sperma gevulde hectocotylus afscheurt, zijnen weg vindt binnen de mantelholte van het wijfjen, en door de uitstorting van zijn' inhoud do berruchting tot stand komen doct.

Terwijl alzoo de verklaring van dit geheel op zich zelf staande feit niet dan met groote inspanniog van krachten gevonden werd, trad, in 1852, op éénmaal vos sIEBOLD op met de verklaring, dat véRAxy en süLLfrk welligt bij nader inzien hınne prioriteitsregten op de ontdekking van den hectocotylus zouden mocten afstaan aan ARISTOTELES. En velen namen de prioriteit van den lantsten aan.

De plaatsen, waarop men zich steunde, meenen wij - na vergelijking, ools van de vertalingen van AUBERT en van camus - aldus te moeten teruggeven :

II ist. aminal, lib. IY, eap. I.

"We Palypus gebruikt zijne armen als voeten en handen; met de twee armen boven den mond haalt hij zijn roedsel naar zich toe. Van den laatsten vangarw echter, die het meest spits is, en de eenige, die witachtig is en aan bet einde in tweeën gespleten, bedient het dier zich bij de paring."

I. $r$, lih. $\mathrm{I}$, cap. 6 .

"Wen beweert ook, dat het mannetjen ecne soort van paringsorgaan bezil aan eenen der vangarmen, aan welken de beide groote zuignaplen zitten; dit deel zou peesachtig zijn, en tot op het midden van den rangarm met dezen vergroeid, terwil dan die arm door het mannetjen in den trechter van het wijfjen zou worden ingebragt."

L. c., lib. V, eap. 12 .

"IInt mannetjen ouderscheidt gich van het wijfjen daardoor, dat zijn kop (volgens de aanmerking van AUnET - in de aangeh, verhandeling uit de \%eitschr. f. W. Z. - wordt daameê, - niettegenstaande 'er кeperivy staat, - het ligchaen bedoeld!) langer is, en dat het aan den arm het door de visschers paringsorgaan genoemde witte deel bezit."

Ziedaar de plaaten, door voN SIERoLd gecitcerd.

Maar in de verhandeling over de voortplanting staat to lezen: (I, \$29.)

"De weekdieren cchter omstrengelen zich in de omgeving der mondopening, daartoe de vangarmen tegen elkander steunende en dooreenstrengelende. Deze wijze van copulatic wordt daardoor noodzakelijk, dat de natuur het deel, waardoor de uitscheiding wordt uitgestort, (de anale opening) zóo heuft gebogen, dat het naast den mond ligt - gelijk dit vroeger in de verhandeling over de deelen der dieren is uiteengezet.... liet kanal nu voor de uitscheiding en voor het eijerstok-achtige deel is cén en hetzelfde, zoowel bij de Malacostraca (onze schaaldieren) als bij deze dieren; en het mannetjen stort door dit kanaal zijn sperma uit. Jet ligt echter op de voorzijle des ligchaams, waar de mantel open is en het zecwater binnendringt. Daarom komt de paring van het manne. ijen met het wijfjen op deze plaats tot stand.... Dat bij de Polyporden 
het mannetjen den vangarm in de "mantelbuis" inbrengt, waarom ook de visschers beweren, dat zij door middel van dien vangarm paren geschiedt alleen tot vasthouden; en wij hebben hier NIET met een aan de voortteling dienstbaar orgaan te doen: immers het ligt buiten den $\pi$ ópos (zie over beteekenis van dit woord, waarvoor hier misschien 't best "geslachtsorganen", zonder meer, werd vertaald, АUвERT, die Cephalopoden d. ARistoteles, p. 20, 21) en buiten het ligchaam."

Wij mogen voor het oogenblik buiten rekening laten, dat de bovengenoemde beschrijringen aan een dier schijnen ontleend te zijn, hetgeen tot hiertoe niet is teruggevonden; want noch op den eigenlijken Hectocotylus, noch op den afwijkend gebouwden arm, die bij alle Cephalopoden - volgens sTEenstruP's belangrijke ontdekking (in 't duitsch in het Archiv für Naturgeschichte, 1856, p. 211-257) - schijnt voortekomen, kunnen zij in haar geheel worden toegepast. Maar men zou bijna vragen: hoe is het mogelijk geweest, op den duur zich met vor sIEBoLn's citaten to vreden te stellen, waarin niets dan onbepaalde uitdrukkingen worden gevonden, en waarvan de grootste kracht nog zou zijn gelegen in cen non-dit." En wij deelen geheel de meening van LEWEs, als hij, ook deze anticipering verwerpende, doet opmerkes, hoe ARISTOTELEs, wanneer hem van het zoo in het oog vallende vrije, zoogenoemd parasiterende, leven van den eigenlijken Hectocotylus iets ware bekend gewcest, ongetwijfeld, vooral in de verhandeling over de voortplanting, daarvan zou hebben gewag gemaakt.

Ware het echter, na de citaten van voN sIEBoLn alleen, nog mogelijk, an een' zoogenoemden gehectocotylisecrden arm te denken van een onbekend gebleven dier; vooral het laatste citaat (merkwaardiger wijze naar het schijnt - door Lewes over het hoofd gezion) bewijst, dunkt mij, met zekerheid, dat Aristoteless van de copulatie der Cephalopoden cene gansch andere voorstelling heeft gehad. Hoe AUBEkT, na dát citaat kan blijven meenen, dat nanistoteles met de hectocotylie eener ons nog onbekende Octopode is bekend geweest", verklaar ik niet te kunnen begrijpen.

Het kwam mij renschelijk voor, mijn stukjen met geene dan de allernoodigste citaten te versieren. Behalve: LEwEs, Aristoteles, Ein Lbschvitt aus der Geschichte der IVissenschaft - übersetzt von JUL. vicron CAnus, Leipzig, 1865, waarvan dit opstel als een referaat mag worden beschouwd - waarbij intusschen, gelijk men - hoop ik - zien zal, de kritick niet is vergeten; verder het bekende werk van JünGEN BONA MEIJE1, Aristoteles' 'Thierkunde, Berlin 1855; en het stukjen van AUBгkT, over de Cephalopoden, heb ik mij bediend van de volgende uitgaven en de daarbij gevoegde aanmerkingen. Voor de Historia asimalium van den 
text met (fransche) vertaling door casius. Parijs 1783; voor de verhandeling over de deelen der dieren van den text en de (duitsche) vertaling van Dr. Frantzius, Leipzig 1853; en voor de verhandeling over de voortplanting en ontwikkeling der dieren van den text en de (insgelijks duitsche) vertaling door AUBERT en wimser, aldaar 1860. In de hollandsche vertalingen, die ik, onder vergelijking van bovengenoemde werken, steeds naar het oorspronkelijke hob gegeven, heb ik zeer vrij vertaald, maar ben ik - zooveel in mijn vermogen was - den zin, door ARISTOTELES in zijne woorden gelegd, getrouw gebleven. Indien het mij niet altoos gelukte, hem wél te verstaan, zal ieder, die uit eigen ondervinding de mocijclijkheid daarvan weet te beoordeelen, mij daarover - hoop ik niet te hard vallen! 





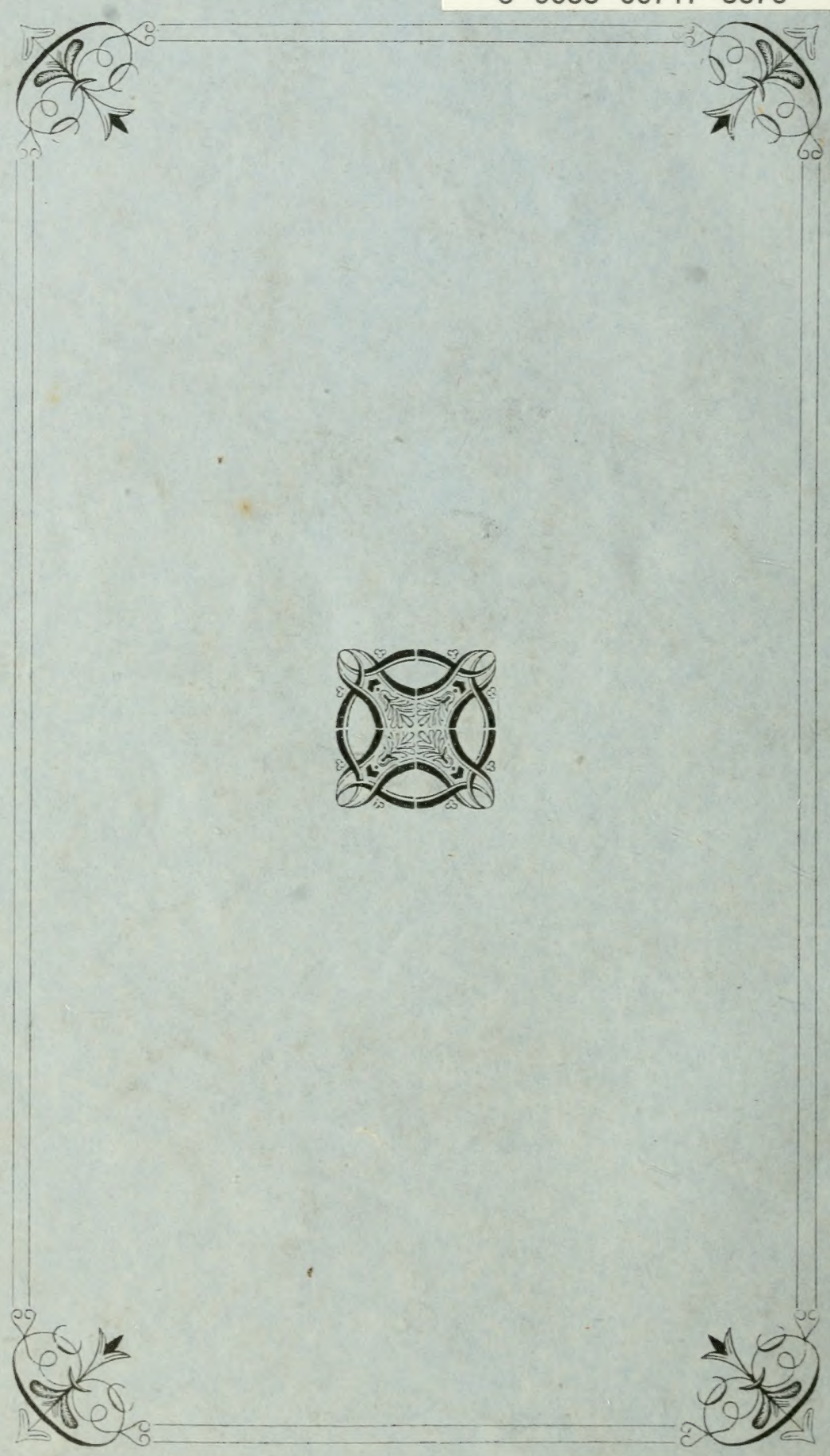

